\title{
O ESTADO JURISDICIONAL COMO OPERADOR DA EXCEÇÃO INTERPRETATIVA SOBERANA
}

\section{THE JURISDICTIONAL STATE AS THE OPERATOR OF SOVEREIGN INTERPRETATIVE EXCEPTION}

\author{
Andityas Soares de Moura Costa Matos ${ }^{1}$ \\ Danton Fillipe Grossi Gangana ${ }^{2}$
}

\section{RESUMO}

O presente artigo analisa a atuação do Poder Jurídico como operador do estado de exceção conforme definido por Giorgio Agamben, principalmente por meio da tradição interpretativista, que novamente assume certo protagonismo com o neoconstitucionalismo. $\mathrm{O}$ trabalho objetiva evidenciar como a interpretação suspende o ordenamento jurídico e produz normas no vazio anômico. Diante da multiplicidade de autores, o presente estudo se limita às técnicas de ponderação e de proporcionalidade de Robert Alexy, tendo em vista a importância que sua teoria assumiu. A metodologia consistiu em uma prévia revisão bibliográfica dos marcos teóricos (Agamben, Alexy, García Amado e Schmitt), analisando-se posteriormente votos proferidos pelos Ministros do Supremo Tribunal Federal em duas importantes decisões recentes, Habeas Corpus $\mathrm{n}^{\circ} 126.292$ e o de ${ }^{\circ} 141.949$. Evidenciou-se assim como o Poder Judiciário, mediante a interpretação jurídica, assume a função de operador do estado de exceção, declarando a suspensão parcial ou total do ordenamento jurídico e produzindo normas exceptivas nesse campo anômico. $\mathrm{O}$ trabalho contribui com as críticas realizadas às técnicas interpretativistas, demonstrando a potência antidemocrática que lhe é própria, apresentando também uma relação entre estado de exceção e interpretativismo jurídico que pode ser aprofundada e aplicada em outros trabalhos.

Palavras-chave: interpretativismo-jurídico; estado de exceção; neoconstitucionalismo; Poder Judiciário; crítica.

\footnotetext{
${ }^{1}$ Graduado em Direito, Mestre em Filosofia do Direito e Doutor em Direito e Justiça, todos pela Faculdade de Direito e Ciências do Estado da Universidade Federal de Minas Gerais (UFMG). Pós-Doutor em Filosofia do Direito pela Universitat de Barcelona (Catalunya), com bolsa da CAPES. Doutor em Filosofia pela Universidade de Coimbra (Portugal). Professor Associado de Filosofia do Direito e disciplinas afins na Faculdade de Direito e Ciências do Estado da UFMG. Membro do Corpo Permanente do Programa de Pós-Graduação em Direito da Faculdade de Direito e Ciências do Estado da UFMG. Professor Visitante na Facultat de Dret de la Universitat de Barcelona entre 2015 e 2016. Professor Residente no Instituto de Estudos Avançados Transdisciplinares IEAT/UFMG entre 2017 e 2018. Lattes: http://lattes.cnpq.br/004102056877552 E-mails: vergiliopublius@hotmail.com e andityas@ufmg.br

${ }^{2}$ Graduado em Direito e Mestre em Filosofia do Direito, todos pela Faculdade de Direito e Ciências do Estado da Universidade Federal de Minas Gerais (UFMG). Lattes: http://lattes.cnpq.br/3889659546172032 E-mails: danton_grossi@hotmail.com e dantongrossi@ufmg.br.
} 


\begin{abstract}
The present essay is an analysis of how the Judicial Branch acts as an operator of the state of exception, as defined by Giorgio Agamben, mainly through the interpretative tradition, that regains a certain protagonism with neoconstitutionalism. The work shows how interpretation suspends the legal order and produces norms in the anomic void. Considering the multiplicity of authors, the analysis was limited to Robert Alexy's ponderation and proportionality techniques, mainly due to the importance of his theory. The methodology consisted of a previous bibliographic review of the theoretical frameworks (Agamben, Alexy, García Amado and Schmitt) and later the analysis of two important recent Brazilian Supreme Court's decisions, Habeas Corpus $\mathrm{n}^{\circ} 126,292$ and $\mathrm{n}^{\circ}$ 141.949. Through this analysis, it was demonstrated how the Judiciary, through legal interpretation, assumes the function of operator of the state of exception, declaring the partial or total suspension of the legal order and producing exceptional norms in the anomic field. The work contributes with the criticisms made to the interpretative techniques, demonstrating the antidemocratic power of this one, also presenting a relation between state of exception and legal interpretivism that can be developed and applied in other essays.
\end{abstract}

Keywords: legal interpretivism; state of exception; neo-constitutionalism; Judicial Branch; criticism.

\title{
INTRODUÇÃO
}

O presente artigo é dividido em três partes. Na primeira parte é realizada uma breve revisão conceitual da definição de estado de exceção, indicando-se os esforços realizados por Giorgio Agamben (2007 e 2010) e a sistematização feita por Andityas Matos (2012) como trabalhos fundamentais para compreender a ideia contemporânea de estado de exceção. Uma definição direta e simples vê no estado de exceção a suspensão parcial ou total do ordenamento jurídico diante de uma emergência a fim de preservar o Estado de Direito e o seu núcleo (MATOS, 2012, p. 281). Um ato ou fato gera uma situação emergencial que põe em risco o Estado de Direito e as relações sociais, e a fim de preservá-las o ordenamento jurídico é suspenso para otimizar a atuação do soberano, permitindo assim a "normalização" da situação. O direito volta a operar e o estado de exceção é desativado. Tratar-se-ia de uma situação provisória. No entanto, o estado de exceção é caracterizado pelo italiano Giorgio Agamben como um paradigma governamental permanente (AGAMBEN, 2007). Essa contradição é explorada na primeira parte do trabalho, tendo em vista uma dimensão ontológica e outra cronológica. 
$\mathrm{Na}$ segunda parte do artigo evidencia-se a tradição interpretativista no Ocidente, partindo do seu atual representante: o neoconstitucionalismo. É realizada uma crítica sobre o conceito e sua suposta inovação, demonstrando-se também o quanto a tradição interpretativista atua às margens do ordenamento, permitindo que o Poder Judiciário afaste a lei e assuma funções legiferantes. A análise tem em vista algumas técnicas interpretativas atuais apresentadas na teoria discursiva e interpretativa de Robert Alexy.

A terceira parte do artigo analisa duas decisões do Supremo Tribunal Federal, no Habeas Corpus $\mathrm{n}^{\mathrm{o}} 126.292$ e no de $\mathrm{n}^{\mathrm{o}} 141.949$, quando os votos de vários Ministros assumem dimensões protagonistas. O emprego da teoria de Alexy, com as técnicas de ponderação e proporcionalidade, reflete o protagonismo que essa teoria assumiu na prática brasileira e latinoamericana. A partir do seu emprego no STF, se evidencia o uso do interpretativismo jurídico como ferramenta de suspensão da ordem jurídica e produção normativa, com a ampliação do poder repressivo do Estado.

\section{TEORIA JURÍDICO-FILOSÓFICA DO ESTADO DE EXCEÇÃO}

Inicialmente é necessário traçar uma noção básica sobre o conceito de estado de exceção. Uma explicação direta enxerga no estado de exceção a "provisória suspensão do direito ou, de modo mais técnico, da Constituição em sua inteireza ou em pontos de grande importância, como, por exemplo, os direitos e garantias fundamentais" (MATOS, 2012, p. 283) diante de situações imprevisíveis e anormais que ameaçam as estruturas do Estado de Direito. São exemplos clássicos as catástrofes naturais e endógenas, as guerras civis ou internacionais e as crises econômicas, ${ }^{3}$ autorizando-se assim a centralização dos Poderes Judiciário, Legislativo e Executivo em um soberano, a quem caberá decidir sobre o estado de exceção, a fim de normalizar a situação exceptiva.

A definição inicial de estado de exceção revela sua operação enquanto estrutura básica do Estado de Direito, sendo inclusive ontologicamente necessária (MATOS, 2012, p. 297). Em situações de quebra da "normalidade", a estrutura normativa não está preparada para atuar. A norma prevê um agir sobre situações previsíveis, inclusive sendo guiada pelo princípio da segurança jurídica. Nesse contexto, a imprevisibilidade momentânea torna necessária uma ação

\footnotetext{
${ }^{3}$ Nesse sentido, Giorgio Agamben faz uma breve exposição da história recente do estado de exceção em Estado de exceção, 2007, p. 24-38, evidenciando as diversas motivações para sua declaração.
} 
não prevista juridicamente, liberando o Estado de Direito das restrições que ele impõe ao seu poder, principalmente tendo em vista a tripartição dos poderes e os direitos e garantias fundamentais.

O estado de exceção só faz sentido em um contexto no qual a norma jurídica seja préestabelecida e tenha a capacidade de submeter e controlar os poderes, ou seja, no Estado de Direito. Não havendo um ordenamento jurídico posto ou em potência, não há o que se suspender. É necessária a existência de uma organização sociopolítica que aspire à estabilidade e à previsibilidade, que tente reduzir o arbítrio potestativo e a concentração de poderes, autorizando apenas provisoriamente a concentração destes e tornando excepcionais as violações aos direitos fundamentais e às garantias constitucionais: “com efeito o estado de exceção apenas se presentifica mediante uma dialética necessária com o Estado de Direito, sob a forma de sua suspensão"(MATOS, 2012, p. 305).

O estado de exceção é, então, um artifício essencial do Estado de Direito desde a sua origem na Constituição Revolucionária Francesa de 1792. É necessário elucidar que o direito continua a existir durante o estado de exceção, estando apenas suspenso. A suspensão não corresponde à negação ou à destruição do direito, "não o elimina e nem o contradiz sistêmica ou performativamente" (MATOS, 2012, p. 305), dado que com a finalidade de realizar o sistema jurídico - seja retomando ou implementando um ordenamento -, o estado de exceção o paralisa. É um erro de análise declarar o fím do Estado de Direito nas claras situações em que seus limites são violados pela exceção; trata-se apenas da sua suspensão.

A justificativa para decretar ou realizar a exceção costuma se assentar na eficácia do método e na violação dos limites que restringem o poder diante da necessidade de realizar certos objetivos emergenciais. O estado de exceção, em seu conceito racionalizado e "juridicizado" pela tradição moderna, sempre tem uma finalidade. A retórica da constitucionalização ou da “juridicização" do estado de exceção aponta como finalidade a normalização de uma situação anormal e imprevisível, competindo ao soberano reconhecer essa situação e, conforme previamente exposto, assumir-se como soberano. O soberano é aquele que, diante de ameaças ao Estado, decide sobre a exceção, decretando e legiferando no vácuo normativo que emerge da suspensão da lei (SCHMITT, 2005, p. 6). Ele opera como se não existissem as limitações normativamente impostas ao poder, aquelas que justificam o Estado de Direito, ou seja, suas normas fundamentais, e passa a acumular as competências dos outros poderes, concentrando a capacidade de legislar e executar as normas. Assim sendo, uma de suas "características 
essenciais é a abolição provisória da distinção entre poder legislativo, executivo e judiciário" (AGAMBEN, 2007, p. 19).

Se o Estado de Direito impõe meios específicos para que certos fins sejam alcançados, ou seja, limita os meios que o poder político pode usar para alcançar as finalidades determinadas pela sociedade, a exceção "se aferra a sua missão de maneira incondicionada e total" (MATOS, 2012, p. 284). O soberano simplesmente rejeita as limitações ao seu poder e fica livre para interferir na esfera jurídica dos sujeitos. A definição de Schmitt ressoa com exatidão nesse momento: "soberano é quem decide sobre a situação em que perde sentido a soberania enquanto instituto meramente jurídico" (MATOS, 2012, p. 295). Sobre a "juridicização” da exceção, há uma longa discussão na teoria jurídica entre aqueles que vislumbram nessa situação uma dimensão predominantemente jurídica e aqueles que a veem como elemento factual (AGAMBEN, 2007, pp. 11-12).

Para o alemão Carl Schmitt, por exemplo, o estado de exceção não pode ser juridicamente determinado, como se tenta fazer nas figuras do estado de sítio ou do estado de necessidade, entre outras tentativas de se circunscrever constitucionalmente o estado de exceção. Segundo o autor, essas tentativas são antes um esforço, dentre tantos outros, do Estado Liberal de "juridicizar" a vida política e não uma representação ou conceituação científica do estado de exceção:

The exception, which is not codified in the existing legal order, can at best be characterized as a case of extreme peril, a danger to the existence of the state, or the like. But it cannot be circumscribed factually and made to conform to a preformed law. The precondition as well as the content of jurisdictional competence in such a case must necessarily be unlimited. From the liberal constitutional point of view, there would be no jurisdictional competence at all. [...] This provision corresponds to the development and practice of the liberal constitutional state, which attempts to repress the question of sovereignty by a division and mutual control of competences. But only the arrangement of the precondition that governs the invocation of exceptional powers corresponds to the liberal constitutional tendency, not the content of article 48 (SCHMITT, 2005, pp. $6,7-11){ }^{4}$

\footnotetext{
${ }^{4}$ Tradução dos autores: “A exceção, que não está codificada na ordem jurídica existente, pode na melhor das hipóteses ser caracterizada como um caso de perigo extremo, um perigo para a existência do Estado, ou algo semelhante. Mas não pode ser circunscrita factualmente e feita em conformidade com uma lei pré-formada. A condição prévia, bem como o conteúdo da competência jurisdicional em tal caso, deve necessariamente ser ilimitada. Do ponto de vista constitucional liberal, não haveria competência jurisdicional em absoluto. [...] Essa disposição corresponde ao desenvolvimento e à prática do Estado constitucional liberal, que tenta reprimir a questão da soberania por meio da divisão e do controle mútuo das competências. Mas apenas a disposição da condição prévia que rege a invocação de poderes excepcionais corresponde à tendência constitucional liberal, e não ao conteúdo do artigo 48". Schmitt se refere aqui ao art. 48 da Constituição de Weimar, responsável pela constitucionalização do estado de exceção na Alemanha a partir de 1919.
} 
Essa percepção comunica-se diretamente com o binômio pessimismo potestativo otimismo normativo, núcleo do Estado de Direito (ZOLO, 2006). Nesse mesmo sentido, o italiano Giorgio Agamben aponta que o estado de exceção não é uma modalidade especial do direito, como seria, e.g., o direito da guerra; ele é a suspensão da própria ordem jurídica (AGAMBEN, 2007, p. 15), estando em uma zona de indeterminação entre direito e fato.

Schmitt acrescenta às características acima relacionadas outros três elementos que alteram a relação Estado de Direito-soberano. Este passa a criar os próprios limites (direito) enquanto aplica a norma, e é capaz, por meio de seus atos, de transformar fato em norma. Nesse ponto há uma zona de indeterminação entre a norma e o fato. O poder soberano é arbitrário, ou melhor, é discricionário, haja vista ser constitucional e legítimo, sendo essa a primeira das características. Em segundo lugar, e claramente conectada com a anterior, há uma presunção de legalidade nos atos praticados pelo soberano, que são imediatamente exequíveis - trata-se da última característica indicada por Schmitt. Essas características também estão presentes em situações não exceptivas, sendo a exceção uma mudança quanto à sua intensidade. O soberano se põe como fora-da-lei, pois não é limitado pelo ordenamento jurídico, suspenso com a declaração da exceção. Mas ao mesmo tempo, ele está incluído no direito sob a forma de sua própria suspensão.

Essa lógica fundamenta o estado de exceção e o direito, que inclui para excluir, suspende a lei para poder aplicá-la. Agamben argumenta como decretos e outros atos executivos passam a ter força de lei - essa ideia será retomada à frente em um paralelo com a força de lei que as decisões, regulamentações e súmulas jurisprudenciais dos tribunais adquiriram no Brasil e no mundo -, o que o autor define inicialmente como "sentido geral de eficácia, de capacidade de obrigar" (AGAMBEN, 2007, p. 59), mas que depois da Revolução Francesa passa a significar um valor superior dos atos parlamentares. A lei ocupa um locus específico no ordenamento jurídico, abaixo da Constituição, mas acima dos decretos e regulamentos do Executivo, sendo limitada por aquela mas limitando estes.

Dois pontos são relevantes nessa digressão: o primeiro é a exequibilidade que os atos do Executivo assumem, evidenciando a confusão de poderes definidora do estado de exceção; o segundo, e mais relevante para o autor italiano, é o isolamento da força de lei perante a lei. Há uma cisão entre a força de lei e a forma de lei, de modo que a lei continua em vigor, mas não se aplica porque está suspensa. No estado de exceção o que existe é força de lei sem lei (AGAMBEN, 2007). Nas palavras de Agamben: “é um espaço anômico onde o que está em 
jogo é uma força de lei sem lei" (AGAMBEN, 2007, p. 61). Nesse sentido, o estado de exceção revela o que é tradicionalmente omitido pelo direito: "a aplicação de uma norma não está de modo algum contida nela. [...] O estado de exceção é, nesse sentido, a abertura de um espaço em que aplicação e norma mostram sua separação em que uma pura força de łei realiza (isto é, aloca desaplicando) uma norma cuja aplicação foi suspensa (AGAMBEN, 2007, p. 63).

Entendemos que o estado de exceção é permanente tanto em sentido ontológico quanto em sentido cronológico. O primeiro sentido comunica-se com a investigação realizada por Giorgio Agamben em Estado de exceção, mais precisamente no capítulo "Luta de gigantes acerca de um vazio". O autor aborda as teorias de Walter Benjamin e Carl Schmitt para evidenciar a discussão sobre o (não) pertencimento do estado de exceção e da violência que o constitui ao contexto jurídico (AGAMBEN, 2007, p. 83-98), pois a suspensão do ordenamento jurídico seria necessária ao direito para que, nas situações imprevisíveis e críticas, o Estado de Direito não se rompa. Ou seja, para que este não chegue ao fim, é prevista a possibilidade da suspensão momentânea do ordenamento jurídico. O estado de exceção, dessa forma, é um "paradigma constitutivo da ordem jurídica" (AGAMBEN, 2007, p. 18). No capítulo citado, Agamben desenvolve essa ideia em outro patamar e aborda a discussão de um ponto de vista constitutivo do direito. Tendo como pano de fundo Benjamin (BENJAMIN, 1986, 1994 e 1984) e Schmitt (SCHMITT 2005, 1992 e 2014), o autor demonstra que o direito é caracterizado por um constante esforço de incluir em sua esfera toda violência, inclusive aquela que emana em um espaço de anomia. Nas palavras do filósofo italiano:

O direito parece não poder existir senão através de uma captura da anomia, assim como a linguagem só pode existir através da captura do não linguístico. Em ambos os casos, o conflito parece incidir sobre um espaço vazio: anomia, vaccum jurídico de um lado e, de outro, ser puro, vazio de toda determinação e de todo predicado real. Para o direito, esse espaço vazio é o estado de exceção como dimensão constitutiva (AGAMBEN, 2007, p. 93).

Esse espaço vazio e anômico criado a partir da suspensão divide o direito em uma instância de pura vigência sem aplicação, a forma de lei, e outra instância de aplicação sem vigência, a força de lei. Nesse sentido, “a exceção não nega ou destrói o direito, mas opera à

\footnotetext{
${ }^{5} \mathrm{O}$ uso do termo "lei” com dois traços [lei] é uma referência à própria escrita adotada por Giorgio Agamben. O filósofo marca a palavra "lei" com um X sobreposto, mas por questões de formatação os autores resolveram adotar neste artigo o duplo tachado. $\mathrm{O}$ italiano usa essa forma de escrita para fazer referência às normas que, durante o estado de exceção, em que há indiferenciação entre norma e fato, não possuem forma de lei, mas apenas sua força.
} 
sua margem para trazê-lo, de novo e nunca, ao centro" (MATOS, 2012, p. 306). A dimensão ontológica do estado de exceção permanente comunica-se diretamente com aquela chamada de cronológica, que é a extensão indeterminada da lógica do estado de exceção e da sua forma de operar para situações de normalidade. Agamben indica que o "estado de exceção tende cada vez mais a se apresentar como o paradigma de governo dominante na política contemporânea" (AGAMBEN, 2007, p. 13). Nesse sentido, percebe-se que a cisão entre força de lei e forma de lei é o que ocupa o campo jurídico do Estado de Direito. O estado de exceção assume um caráter permanente, não sendo mais um estágio, uma situação ou uma condição provisória, apresentando feições de forma estatal autônoma. O estado de exceção transforma-se assim em um paradigma governamental e transmuta-se para um Estado de Exceção (MATOS, 2012, p. 298).

O estado de exceção enquanto paradigma governamental evoca a tradição do Estado de Direito que anuncia a democracia ao mesmo tempo que a nega mediante a representação política (WOOD, 2003), ou seja, anuncia a soberania do povo e a nega com a transferência de poder aos seus representantes, limitando e suspendendo a vontade popular para garantir a estabilidade do Estado. Essa noção está presente na tradição liberal, para a qual "nenhum sacrifício pela nossa democracia é demasiado grande, menos ainda o sacrifício temporário da própria democracia" (ROSSITER, 2013, p. 483). O estado de exceção cria o espaço que possibilita ao soberano tornar inoperantes os resultados legislativos da democracia popular, a fim de manter a dinâmica da democracia representativa e dos direitos-privilégios operantes.

Essa denúncia é realizada por Agamben e retomada por Matos, que indica a "transformação da emergência em regra", acompanhada de um "esvaziamento das instâncias populares de criação do direito" e do aumento do poder dos aparelhos de direção da exceção que levam a um Estado de Exceção. Nas palavras do brasileiro: “O Estado de Exceção se manifestaria então quando a soberania popular se visse substituída pela tecnocracia no que diz respeito à tomada de decisões necessárias à manutenção do Estado de Direito, o que é, obviamente, paradoxal (MATOS, 2012, p. 298). O autor aponta como órgãos técnicos principalmente aqueles submetidos ao Poder Executivo, como o Banco Central e a Secretaria da Receita Federal, além das organizações econômicas internacionais, que assumem funções decisórias. Mas é possível estender essa visão quanto à tecnocracia ao direito processual, que representa a conexão da norma com a sua aplicação, da forma de lei com a força de lei. Trata- 
se de uma maneira de obscurecer, a partir de uma técnica procedimental, o que de fato sustenta a decisão: a violência.

\section{A EXCEÇÃO JUDICIAL NO NEOCONSTITUCIONALISMO}

Postas as linhas gerais sobre o estado de exceção e o duplo significado que o adjetivo "permanente" assume nesse contexto, cabe agora evidenciar como a atuação do Poder Judiciário, por meio de sua técnica interpretativista, traduz-se em ativismo jurídico e se comunica com a suspensão do direito. Pretende-se demonstrar como o Poder Judiciário abre um campo de arbitrariedade com seus atos interpretativos e como, na busca por uma aplicação ponderada do direito, acaba suspendendo-o e realizando a cisão entre forma de lei e força de lei, fundamental ao estado de exceção. As técnicas interpretativas possuem longa tradição e hoje têm no neoconstitucionalismo seu principal representante. Partir-se-á dele para analisar as continuidades históricas importadas e reproduzidas, para trazer à luz o aumento do protagonismo judicial no estado de exceção.

Importante salientar que o interpretativismo aqui referenciado é um movimento que se baseia nas técnicas de interpretação, sobretudo da Constituição, possibilitando uma tese favorável à interpretação criativa. O interpretativismo possibilita que os julgadores façam maior uso dos princípios jurídicos na aplicação da norma e na argumentação jurídica. A partir de uma ampliação da aplicação de princípios surgem variadas técnicas que tentam dar uma dimensão não-literal a esses enunciados normativos. Apesar da diversidade de técnicas, há algumas semelhanças como a utilização dos métodos de ponderação ou balanceamento (Cf. POZZOLO, 1998).

Segundo Dimitri Dimoulis, autores como Robert Alexy, na Alemanha, Ronald Dworkin, nos EUA, Luigi Ferrajoli, na Itália, Carlos Santiago Nino, na Argentina e Manuel Atienza, na Espanha (DIMOULIS, 2008, p. 16) são os principais representantes do neoconstitucionalismo em âmbito internacional, cabendo a Luís Roberto Barroso, Ministro da corte constitucional brasileira, o Supremo Tribunal Federal, um importante papel no debate sobre o tema no Brasil. É necessário indicar que o conceito de neoconstitucionalismo está em disputa, sendo impossível oferecer uma definição absoluta ao movimento. Nesse sentido, o livro El canon neoconstitucional, organizado por Miguel Carbonell e Leonardo García Jaramillo, reúne importantes textos sobre distintas concepções relativas ao neoconstitucionalismo. Os autores 
afirmam que não pretendem encerrar o tema, apenas sistematizar e reunir algumas ideias (CARBONELL; JARAMILLO, 2010, p. 14).

Uma dentre essas várias concepções sobre o neoconstitucionalismo é a de Carbonell. Segundo o autor, trata-se de movimento teórico e prático que pretende explicar o conjunto de Constituições que começam a surgir depois da Segunda Guerra Mundial, sobretudo a partir dos anos setenta do século XX. O autor indica que uma característica marcante dessas Constituições é a reunião de um amplo catálogo de direitos fundamentais, o que representa um novo marco nas relações entre Estado e cidadãos (CARBONELL, 2010, p. 161). Novos parâmetros interpretativos surgem a partir dessas novas Constituições, sendo que a atuação e a fundamentação das decisões judiciais se tornam mais complexas, gerando técnicas interpretativas próprias como a ponderação, a proporcionalidade, a razoabilidade, a maximização dos efeitos normativos dos direitos fundamentais e a irradiação dos princípios (CARBONELL, 2010, p. 161). Essas técnicas passam a ser centrais para os atos decisórios das cortes constitucionais e dos juízes em geral.

Da mesma forma que a Constituição do neoconstitucionalismo possui um aspecto alargado, o juiz passa a atuar com maior presença nos atos da vida social. O neoconstitucionalismo gera uma maximização nas atividades judiciais, o que torna o ativismo judicial presente em uma proporção muito superior ao que já se havia observado em outros períodos históricos. A novidade não está nos três elementos definidores do neoconstitucionalismo - Constituições substantivas, ativismo judicial e pós-positivismo isoladamente tomados, mas em sua conjunção. Para Carbonell, quando esses elementos compartilham o mesmo tempo e espaço, produzem algo novo, gerando uma ruptura com os movimentos anteriores (CARBONELL, 2010, p. 166). O neoconstitucionalismo, portanto, indicaria a presença de uma Constituição substantiva interpretada por meio de determinadas técnicas e aplicada com certo ativismo judicial de acordo com postulados pós-positivistas.

A proposição de Carbonell se aproxima, em certa medida, da visão de Luís Roberto Barroso, cuja produção teórico-prática será analisada no presente artigo por possibilitar uma crítica não só dos conceitos de que faz uso, mas da sua prática como julgador. O estado de exceção não é uma teoria estranha à realidade, pois parte dela e busca nela sua confirmação. Dessa feita, Barroso conceitua neoconstitucionalismo nos seguintes termos:

Em suma: o neoconstitucionalismo ou novo direito constitucional, na acepção aqui desenvolvida, identifica um conjunto amplo de transformações ocorridas no 
Estado e no direito constitucional, em meio às quais podem ser assinalados, (i) como marco histórico, a formação do Estado constitucional de direito, cuja consolidação se deu ao longo das décadas finais do século XX; (ii) como marco filosófico, o pós-positivismo, com a centralidade dos direitos fundamentais e a reaproximação entre Direito e ética; e (iii) como marco teórico, o conjunto de mudanças que incluem a força normativa da Constituição, a expansão da jurisdição constitucional e o desenvolvimento de uma nova dogmática da interpretação constitucional. Desse conjunto de fenômenos resultou um processo extenso e profundo de constitucionalização do Direito (BARROSO, 2005, pp. 1112).

Nossa atenção será voltada para o ponto (iii), isto é, o marco teórico de mais centralidade na definição do movimento jurídico em debate e que possui maior potencial de distinção do neoconstitucionalismo diante de outras escolas jurídicas. Mas é necessário apontar, ainda que de forma breve, a vagueza que circunda os outros dois pontos, (i) e (ii). O marco histórico indicado pelo autor é a suposta "formação" do Estado constitucional de direito nas décadas finais do século XX. Essa definição cria a necessidade imediata de se responder ao menos a duas perguntas: o que o autor quer dizer com "Estado constitucional de direito"? E no que essa forma de Estado seria distinta das demais, a ponto de ser possível indicar seu surgimento apenas ao fim do século XX?

A primeira pergunta é respondida com pouca precisão ou rigor, pois Barroso sugere que esse Estado é definido por uma "aproximação das ideias de constitucionalismo e de democracia", tendo produzido "uma nova forma de organização política, que atende por nomes diversos: Estado democrático de direito, Estado constitucional de direito, Estado constitucional democrático" (BARROSO, 2005, p. 3). Essa relação teria sido responsável por uma redefinição do "lugar da Constituição e a influência do direito constitucional sobre as instituições contemporâneas" (BARROSO, 2005, p. 4).

Ora, um estudo atento da história do Estado e da Constituição indica que o projeto de união do Estado de Direito com a democracia remonta à Revolução Francesa e ao processo de expansão do sufrágio nos Estados Unidos da América. A democracia representativa como forma de decisão e organização política constitui a resposta de uma elite econômica e política aos desejos democráticos da sociedade, sendo o Estado de Direito uma tentativa de limitação do poder político mediante normas fundamentais da ordem político-jurídica que protegem o indivíduo e seus direitos, em especial a liberdade-propriedade, ameaçada pelas "classes 
suínas". ${ }^{\circ}$ Assim, a contextualização de Barroso é, no mínimo, negligente. Certamente há alguma particularidade no contexto do pós-segunda guerra, mas é necessário ser mais rigoroso com essa caracterização.

O trauma político do Ocidente com a emergência do fascismo e do nazismo no berço do que é considerado o padrão de civilidade do mundo põe em evidência a "força terrível do poder, a fragilidade do indivíduo, a inadequação das salvaguardas até aquele momento estabelecidas" (COSTA, 2010, p. 242). A cultura que emerge desse trauma totalitário é o que melhor define as particularidades da segunda metade do século XX e o seu constitucionalismo, que busca oferecer uma resposta às questões colocadas em evidência pelas experiências totalitárias. A reação direta é a declaração em âmbito nacional e internacional de princípios e direitos fundamentais sem um fundamento preciso, ou seja, infundados (COSTA, 2010, p. 240). São direitos que fundamentam a ordem jurídica, mas que na busca de uma universalidade rejeitam um fundamento único e se centram no objetivo de proteger as pessoas simplesmente por serem pessoas. Nesse sentido, os direitos fundamentais estão previstos em cartas constitucionais e em declarações internacionais, não operando apenas como regras, mas como princípios, quer dizer, como a tradução de projetos políticos. A previsão constitucional ou convencional (convenções e tratados internacionais) supostamente gera uma pressão interna no ordenamento, de modo que esses princípios cumprem a função que cabia aos direitos naturais no século XVIII: denunciar a ordem existente e prometer uma ordem futura diferente (COSTA, 2010, p. 246). Conclui Pietro Costa: "Nos novos ordenamentos constitucionais são os princípios e os direitos fundamentais que, de dentro do ordenamento, indicam as formas e a direção da sua transformação" (COSTA, 2010, p. 246).

Barroso parte da consequente valorização dos princípios e aponta erroneamente para uma estreita conexão entre o positivismo e os supostos abusos cometidos nos regimes nazifascistas. Para ele, a decadência do positivismo é "emblematicamente associada à derrota do fascismo na Itália e do nazismo na Alemanha, regimes que promoveram a barbárie sob a proteção da legalidade. Ao fim da $2^{a}$ Guerra, a ética e os valores começam a retornar ao Direito" (BARROSO, 2005, p. 4). A ética e os valores citados correspondem aos princípios e direitos fundamentais que sempre teriam estado presentes, mas que passaram a ser ponto de referência obrigatório para a interpretação e a aplicação das normas jurídicas apenas com a derrocada do

\footnotetext{
${ }^{6}$ Expressão utilizada pelo liberal Edmund Burke para se referir à classe trabalhadora ao analisar o processo revolucionário francês (BURKE, 2003, pp. 42-43).
} 
positivismo jurídico. Assim, o neoconstitucionalismo aparentemente conferiria a esses princípios e direitos fundamentais um lugar privilegiado, pois estariam acima da vontade dos poderes e dos atores políticos, bem como salvaguardados de qualquer decisionismo, incluindo o soberano poder do povo. Eles pertencem ao âmbito do não decidível (FERRAJOLI, 2014, p. 36).

A postura de Barroso de conectar a prática de um positivismo legalista ao regime nazista não poderia estar mais equivocada, tal como demonstram inúmeros estudos há mais de 30 anos. Tal tese é exposta por Andityas Matos e Joyce Souza no artigo Sobrevivências do nazifascismo na teoria jurídica contemporânea e seus reflexos na interpretação judicial brasileira (2017). As autoras demonstram, por meio de análise direta de textos dos teóricos que fundamentaram a atuação do Judiciário durante o regime nazista, que a atuação e a fundamentação dos juízes alemães utilizou-se de forma intensa de princípios gerais e fontes supralegais tais como o "espírito do povo", o "bem comum", a "moral social”, o "interesse público" etc. Segundo as autoras: "os juízes nazistas desenvolveram práticas interpretativas e argumentativas que, desprezando a lei - entendida como um anacronismo liberal -, apontavam para uma noção substancial de direito e de justiça” (MATOS; SOUZA, 2017, p. 301). Elas demonstram ainda, com fontes alemãs dos anos 30, que o fundamento das decisões jurídicas durante o III Reich não se deveu a um respeito injusto à lei ou a um positivismo cego, mas sim a interpretações discricionárias e contra legem de juízes políticos, muito semelhantes a seus congêneres no constitucionalismo, ao menos em termos estruturais. Com efeito, os juízes nazistas se diziam capazes de revelar a vontade uniforme do sujeito político "povo" e se opunham à lei, que operava como um limite intolerável 'à tarefa de 'fazer justiça', o que só poderia ser realizado de maneira perfeita levando em consideração os valores e as tradições superiores do povo alemão" (MATOS; SOUZA, 2017, p. 300). É evidente a fragilidade do argumento relativo ao marco histórico utilizado por Barroso, que ainda será retomado em uma análise comparativa para evidenciar que a ideia de inovação devida ao neoconstitucionalismo não se sustenta.

Barroso também aponta um novo marco filosófico, o pós-positivismo, definido pelo autor como a junção do jusnaturalismo e do positivismo jurídico. Barroso aduz que nesse novo marco "a interpretação e aplicação do ordenamento jurídico hão de ser inspiradas por uma teoria de justiça, mas não podem comportar voluntarismos ou personalismos, sobretudo os judiciais" (BARROSO, 2005, p. 5). Esse elemento e o anterior acabam por direcionar ao último dos três indicados pelo autor: o marco teórico. Ele é subdividido em três pontos: a) reconhecimento da 
força normativa da Constituição; b) expansão da jurisdição constitucional; c) nova interpretação constitucional.

O primeiro ponto, reconhecimento da força normativa constitucional, é entendido como uma ruptura com o "modelo que vigorou na Europa até meados do século passado, no qual a Constituição era vista como um documento essencialmente político, um convite à atuação dos Poderes Públicos" (BARROSO, 2005, p. 5). Barroso afirma que esse novo paradigma atribui certo protagonismo ao Judiciário na efetivação da Constituição, que passou a ter sua força normativa e o caráter vinculativo e obrigatório de suas disposições reconhecidos. No entanto, o reconhecimento da força normativa constitucional não é uma novidade na tradição do pensamento e das práticas judiciárias, como bem apontado por Dimitri Dimoulis (DIMOULIS, 2008, p. 3): "as Constituições escritas-instrumentais que proliferaram na Europa e na América Latina desde o início do século XIX, seguindo o exemplo dos EUA e da França, foram sempre e necessariamente vistas como superiores à legislação ordinária". O autor grego inclusive retorna aos séculos XVIII e XIX para demonstrar que o marco teórico apontado por Barroso como uma "inovação do neoconstitucionalismo" já está presente em Sieyès (DIMOULIS, 2008, p. 3) durante o processo revolucionário francês e em François Guizot na década de 1830. Com efeito, em seu Cours de droit contitutioneel de 1866, Pellegrino Rossi anota:

[a] Exposição da Carta constitucional e das garantias individuais, assim como das instituições políticas que a Carta consagra. Não se trata mais de um simples sistema filosófico entregue às disputas pessoais. É uma lei escrita, reconhecida que pode e deve ser explicada, comentada, da mesma maneira como a lei civil ou qualquer outra parte de nossa legislação (apud DIMOULIS, 2008, p. 5).

Além da França, outros países também liam suas Constituições nesse sentido, muito antes da moda neoconstitucionalista. Na Itália, para citar um dos países exemplificados por Barroso em seu texto, Paolo Biscaratti di Ruffía afirma que os Estados italianos reivindicavam desde o início do século XIX uma Constituição capaz de introduzir os princípios liberais para realizar a instituição de órgãos parlamentares representativos, assim como garantir um mínimo de direitos públicos subjetivos aos cidadãos (RUFFÍA, 1966, p. 7). A força normativa da Constituição não é uma inovação do neoconstitucionalismo, mas um resultado do tradicional constitucionalismo estadunidense do século XIX, que atribuiu ao Poder Judiciário um papel ativo na defesa da Constituição e dos direitos nela presentes. O caso mais emblemático e clássico ocorreu em 1803, com a decisão sobre competência e constitucionalidade no caso 
Marbury vs Madison, ${ }^{7}$ no qual um juiz da corte constitucional estadunidense decidiu que uma lei do Congresso violava as regras de competência presentes na Constituição e, portanto, era inválida e não poderia ser aplicada ao caso concreto. O Poder Judiciário foi ativo desde o início do constitucionalismo, defendendo a superioridade constitucional e tutelando os direitos fundamentais, sempre tendo força para anular e modular as decisões dos demais poderes.

A tradição neoconstitucionalista costuma apontar o caso supracitado, e os EUA por inteiro, como exceção à regra (BARROSO, 2005, p. 14). Tal afirmação não possui qualquer respaldo em uma bibliografia mais cuidadosa. Há significativos casos de controle de constitucionalidade em todo o mundo ocidental, a exemplo da Grécia, como indicado por Dimoulis (2003), da Noruega, como demonstrado por Deener (1952), ou da Suíça, cuja Constituição Federal de 1874 já previa um controle limitado das leis dos cantões. ${ }^{8}$ E isso apenas considerando o controle realizado pelo Poder Judiciário, sendo necessário atentar para o controle prévio realizado pelo Legislativo e pelo Executivo, dado que tais poderes devem observar as determinações da Constituição para realizar seus atos, sejam leis, regulamentos, decretos etc. Nesse contexto, o neoconstitucionalismo parte de uma premissa bem frágil, segundo a qual a ausência de um Poder Judiciário competente para avaliar as violações da Constituição levaria necessariamente à violação desta pelo Poder Legislativo. É claro que parece interessante a presença de um poder independente que possa corrigir possíveis violações constitucionais e aplicar sanções aos agentes que ajam fora dos limites impostos pela Constituição, mas a presença desse poder também gera outro ator político que, por sua vez, também pode violar as normas constitucionais. A pressuposição de que a ausência do Poder Judiciário "neoconstitucionalizado" leva à violação da Constituição pelos outros poderes ratifica uma posição muito cara a Barroso e a outros autores que seguem sua linha, indicando a percepção de que o Judiciário teria uma maior aptidão e uma racionalidade mais adequada para

\footnotetext{
${ }^{7}$ Marbury vs. Madison é a decisão mais importante do direito constitucional clássico estadunidense. Ela estabeleceu a autoridade para o Judiciário rever a constitucionalidade dos atos executivos e legislativos. Embora a Constituição seja omissa quanto a tal autoridade, esse poder existe desde Marbury (CHEMERINSKY, 2015, p. 74).

8 “Art. 113. A Suprema Corte Federal também é responsável pela adjudicação: 1. em conflitos referentes à competência entre autoridades federais e autoridades cantonais; 2. em disputas de natureza constitucional entre cantões 3. em queixas em relação a violações de direitos constitucionais dos cidadãos, bem como os relacionados a violações de tratados e pactos de natureza privada. Cabe à legislação federal determinar as disputadas administrativas. Em todos esses casos, no entanto, as leis aprovadas pela Assembleia Federal e as resoluções geralmente vinculantes, bem como os tratados estatais aprovados por ela, são relevantes para a Suprema Corte Federal.” Disponível em: $<$ http://www.verfassungen.ch/verf74-1.htm>. Acesso em: 05 mai. 2019 (tradução nossa).
} 
controlar e resguardar as normas constitucionais, com o que se justificaria a defesa de um maior protagonismo dos juízes.

Os exemplos históricos de práticas e de teorias jurídicas brevemente indicados acima demonstram que o primeiro marco teórico acerca da força normativa da Constituição não surge na segunda metade do século XX, mas nas últimas décadas do século XVIII, e tem sido posto em prática desde as primeiras décadas do século XIX. A força normativa da Constituição é uma realidade há algum tempo e, como aponta Dimitri Dimoulis: "não conhecemos Constituição que desminta a regra da superioridade jurídica e do caráter material, valorativo e claramente político de seu conteúdo" (DIMOULIS, 2008, p. 5).

O segundo marco teórico - que se comunica diretamente com o primeiro e, por conseguinte, com as críticas a ele dirigidas - do neoconstitucionalismo seria a "expansão da jurisdição constitucional e tutela dos direitos fundamentais" (BARROSO, 2005, p. 5). Para Barroso, essa expansão resulta da passagem de um modelo legislativo de poder para um constitucional, no qual se reafirma a supremacia da Constituição e se transfere a tutela dos direitos fundamentais do Poder Legislativo para o Poder Judiciário, o que, em tese ${ }^{9}$, os protegeria dos processos políticos majoritários (BARROSO, 2005, pp. 6-7). Além disso, o autor faz referência à expansão geográfica do controle de constitucionalidade, que passou a ser previsto em diversos países.

De fato houve uma expansão do controle judicial logo após a Segunda Guerra Mundial, tanto no sentido geográfico quanto no sentido interno dos ordenamentos. Todavia, a ampliação geográfica desse processo é um fenômeno que não deriva de uma teoria ou prática judicial, mas da ocidentalização do mundo e da consequente importação dos modelos políticos europeus por países latino-americanos, africanos e asiáticos.

O neoconstitucionalismo vê a transferência da tutela dos direitos fundamentais para o Poder Judiciário como algo positivo por aumentar a já larga distância entre as decisões sobre os direitos e os sujeitos que serão governados por eles, dado que os direitos devem ser protegidos dos "projetos políticos majoritários”. A ideia não é nova e está presente já há algum tempo na tradição liberal, que acusa o projeto totalitário de um excesso democrático. Todavia, tal ideia desconsidera completamente o fato de haver maior concentração de poder nesses

\footnotetext{
9 Basta atentar para os últimos anos no Brasil - quando decisões com bases constitucionais foram responsáveis pela flexibilização e pelo enfraquecimento de garantias constitucionais, como a prisão antes do trânsito em julgado ou a permissão de mandatos de busca e apreensão coletivos - para perceber a fragilidade dessa suposição.
} 
Estados liberais, dado que a representação política desconsidera a democracia efetiva e, mediante a representação política, aniquila as diferenças ao formar o Uno, algo similar ao projeto homogêneo do nazifascismo. Por seu turno, a democracia radical não representativa de formações não liberais como os sovietes, a Comuna de Paris e Rojava assume um projeto de comunicação entre as diferenças que jamais se sintetizam em uma unidade transcendente, tal como demonstrado por Andityas Matos em Representação política contra democracia radical: uma arqueologia (a)teológica do poder separado (MATOS, 2019). Em definitivo: o constitucionalismo defende a tradicional e paradoxal ideia de que quanto mais longe o poder estiver dos cidadãos, melhor o governo será para elas.

O processo de concentração do papel de guardião da Constituição nas cortes constitucionais leva a uma limitação das outras instâncias de poder, inclusive aquelas não institucionais e populares, e reduz a capacidade de instâncias inferiores dentro do próprio Poder Judiciário de também exercer suas funções. As consequências desse aumento de protagonismo, tendente ao monopólio, do Poder Judiciário não são necessariamente positivas, não sendo apresentado por Barroso nenhum argumento que evidencie algo nesse sentido. Inclusive, não há indicador histórico ou político que garanta um distanciamento axiológico e institucional entre as cortes constitucionais e os outros poderes. Ao contrário, é evidente em regimes autoritários justamente uma aproximação entre o Judiciário e o Executivo, como ocorreu nas ditaduras latino-americanas, no nazismo e no fascismo italiano, dentre tantos outros exemplos da história. Pode-se concluir a análise desse segundo ponto com a observação de Dimoulis de que "nem o controle judicial concentrado nem a maior tutela dos direitos fundamentais (e muito menos a conexão causal desses dois elementos) podem ser vistos como traços peculiares do neoconstitucionalismo" (DIMOULIS, 2008, p. 10).

O último marco apontado por Barroso e pelos adeptos do neoconstitucionalismo é "a nova interpretação constitucional” (BARROSO, 2005, p. 8), que supostamente inova ao superar uma tradição cuja "resposta para os problemas está integralmente no sistema jurídico e o intérprete desempenha uma função técnica de conhecimento, de formulação de juízos de fato" (BARROSO, 2005, p. 9). O intérprete deixa de ter função meramente técnica e "torna-se coparticipante do processo de criação do Direito, completando o trabalho do legislador, ao fazer valorações de sentido para as cláusulas abertas e ao realizar escolhas entre soluções possíveis" (BARROSO, 2005, p. 9). Essa modificação é, entretanto, uma consequência natural da força normativa que a Constituição passa a ter, o que não é algo novo, como demonstrado acima, 
transferindo ao campo jurídico a competência para a definição do conteúdo dos princípios e das cláusulas gerais. Estas, também chamadas de conceitos jurídicos indeterminados, são normas amplas e com sentido aberto, que não possuem em si todos os elementos para a sua aplicação. Exemplos clássicos são as noções de "ordem pública", "interesse social” e "paz social”. Por não possuírem um significado objetivo, tais expressões atribuem maior discricionariedade ao juiz e a seus atos interpretativos, de modo que a definição dos princípios permite que a significação do conteúdo das cláusulas gerais e centrais dos sistemas jurídicos, tais como "dignidade da pessoa humana", "razoabilidade", "solidariedade" e "eficiência", sejam transferidos aos intérpretes, que assumem novamente uma importante tarefa discricionária.

A possibilidade de definição desses conteúdos inaugura, de acordo com o neoconstitucionalismo, uma novidade interpretativa capaz de ampliar a atuação do Judiciário. No caso de colisões de normas constitucionais, o Poder Judiciário faz uma análise dos conteúdos dos princípios e dos direitos fundamentais determinando a sobreposição de um sobre o outro, de modo que, “[n]estes casos, a atuação do intérprete criará o Direito aplicável ao caso concreto" (BARROSO, 2005, p. 11). A nova técnica utilizada pelo intérprete é a ponderação de princípios, bens ou valores jurídicos professados pelo juiz. O intérprete "procederá à escolha do direito que irá prevalecer, em concreto, por realizar mais adequadamente a vontade constitucional” (BARROSO, 2005, p. 11).

Conforme aponta Virgílio Afonso da Silva - tradutor e aluno de Robert Alexy e um dos principais representantes teóricos das técnicas de ponderação no Brasil -, o conceito que guia essa nova interpretação constitucional é a ponderação ou proporcionalidade, que tem como finalidade controlar os atos legislativos e executivos reduzindo a restrição dos direitos somente ao necessário (SILVA, 2002, pp. 27-28). Há diversas teorias que tentam realizar uma sistematização da técnica da proporcionalidade ou ponderação, sendo de grande destaque o trabalho de Robert Alexy. Sua importância é comprovada pelo constante emprego de suas teorias nos julgamentos constitucionais, ${ }^{10}$ sendo também atestada por Manuel Atienza, que

\footnotetext{
${ }^{10}$ Em consulta simples ao site do Supremo Tribunal Federal (STF), foram levantadas 75 citações em Acórdãos proferidos em julgamentos do pleno e 10 (dez) referências em decisões do Presidente do STF. O refinamento da pesquisa, com análise dos julgados e do teor das citações, indicou importantes decisões recentes da Corte que merecem destaque, quais sejam: ação sobre a formalidade do impeachment de Dilma Roussef (ADPF 378); financiamento de campanhas políticas por pessoas jurídicas (ADI 4.650); possibilidade de progressão de regime durante cumprimento da pena em crimes hediondos (HC 82.959-7); uso de célulastronco embrionárias em pesquisas cientificas com finalidades terapêuticas (ADI 3.510); prisão civil do depositário infiel (RE 466.343-1); constitucionalidade da criminalização do aborto de fetos anencéfalos (ADPF 54); possibilidade de repropositura de ação de paternidade na ausência de exame de DNA no âmbito
} 
aponta a relevância da técnica da ponderação em vários tribunais latino-americanos, principalmente nas cortes constitucionais, indicando que o processo é "em grande parte consequência da recepção de ideias sobre Robert Alexy” (ATIENZA, 2014, p.13).

\section{A TEORIA DE ALEXY: INTERPRETAÇÃO OU CRIAÇÃO (ELITISTA) DO DIREITO?}

A posição de Atienza destaca a natureza supostamente técnica que o conceito proporcionalidade apresenta, e nesse sentido é importante apontar que os mais diversos tribunais, da Espanha ao Peru, o adotam. Já as cortes constitucionais brasileiras apresentam um emprego vacilante entre os próprios membros do STF. Entretanto, o desvio teórico não será o centro de nossa análise, haja vista a crítica se dirigir à raiz teórica do conceito e não à sua transposição errônea em determinadas questões factuais.

Alexy fundamenta a regra da proporcionalidade na necessidade de normatizar a interpretação e a aplicação dos princípios e direitos fundamentais pelo Poder Judiciário quando ele deve realizar o controle de atos estatais que concomitantemente visam a realizar um princípio mas acabam por restringir outro. A aplicação dessa técnica tem como objetivo garantir que as restrições aos direitos fundamentais não sejam desproporcionais. Assim, o princípio da proporcionalidade se apresenta como um meta-princípio. Nas palavras de Manuel Atienza:

Quando existem conflitos entre direitos (ou entre princípios, que ocorrem em todos os campos da lei) eles devem ser resolvidos aplicando um teste de proporcionalidade, isto é, aplicando o princípio da proporcionalidade que, para Alexy, se torna um tipo de meta-princípio ou, se preferir, o princípio último do sistema legal (ATIENZA, 2014, p. 13).

A estrutura da ponderação se divide em três momentos, que impõem três exames necessários ao ato estatal de realização/violação dos direitos fundamentais e/ou interesses públicos: a) exame de adequação; b) exame de necessidade; c) exame de proporcionalidade em sentido estrito (ATIENZA, 2014, p. 13). Esses três exames são, por isso, considerados como sub-regras da regra da proporcionalidade (SILVA, 2002, pp. 24, 33, 37), desaguando em um princípio de otimização quanto ao que é factualmente e legalmente possível. Os princípios de

da ação original (RE 363.889); decisões sobre restrições ao direito de imprensa (ADPF 130) e (ADI 4.451); constitucionalidade da tipificação do porte de armas sem munição (HC 104.410); possibilidade de execução provisória de pena antes de sentença final condenatória transitada em julgado (HC 126.292); prescrição retroativa com base na pena (HC 122.694); e demarcação de terras quilombolas (ADI 3.239). 
adequação e necessidade dizem respeito à possibilidade factual de realização dos direitos fundamentais e princípios constitucionais, enquanto o último sub-princípio, o da proporcionalidade em sentido estrito, remete à análise da possibilidade legal (ALEXY, 2014, p. 52).

O subprincípio da adequação serve para se saber se a adoção de um meio de realização ou fomento de um princípio $\mathrm{X}$, que simultaneamente impede ou colide com, ao menos, outro princípio Y, tem capacidade fática de fomentar o primeiro. Se desse meio restritivo não decorre necessariamente a realização ou fomento do princípio $\mathrm{X}$, o ato deve ser afastado por não ser adequado, pois viola a primeira sub-regra da ponderação (ALEXY, 2014, p. 53). É necessário apontar que esse sub-princípio corresponde à razoabilidade, comumente confundida com o princípio geral da proporcionalidade, conforme pontua Virgílio Afonso da Silva: "O conceito de razoabilidade (...) corresponde apenas à primeira das três sub-regras da proporcionalidade, isto é, apenas à exigência de adequação. A regra da proporcionalidade é, portanto, mais ampla do que a regra da razoabilidade, pois não se esgota no exame da compatibilidade entre meios e fins" (SILVA, 2002, p. 33).

Um exemplo de aplicação da adequação está na ADIn (Ação Direta de Inconstitucionalidade) $n^{\circ} 855-2$, que declarou inconstitucional a Lei Estadual do Paraná $n^{\circ}$ 10.248/1993, cujo objetivo era fomentar a proteção dos direitos dos consumidores e, para tanto, determinava que as empresas fossem obrigadas a realizar a pesagem de botijões de gás na presença dos clientes e indicar que os novos botijões estavam cheios ou abater seu valor caso os recolhidos ainda tivessem gás. O princípio que se pretendia alcançar era o da proteção dos direitos dos consumidores e o princípio aparentemente violado foi o da livre iniciativa privada, ao impor às empresas de um ramo obrigação sem ligação a questões de segurança pública ou para seu mero funcionamento. A decisão declarou a lei inconstitucional com base em um relatório do Inmetro que indicou que a balança precisaria ser de altíssima precisão e deveria ficar em local estável, o que reduziria o acesso dos consumidores aos produtos, dada a dificuldade de transporte dos botijões de gás e considerando o fato de serem comprados remotamente através de ligações telefônicas. Assim, uma impossibilidade factual fez com que o ato legislativo do estado do Paraná fosse declarado inconstitucional.

O segundo subprincípio é o da necessidade, em que se pondera sobre as possibilidades de realização dos princípios. Se existirem duas formas semelhantes ou próximas de realizar o princípio $\mathrm{P}_{1}$, deve-se escolher aquela que interfere menos em outro princípio $\mathrm{P}_{2}$. Essa análise 
recai somente quando apenas dois princípios estão em colisão; no caso de haver um terceiro princípio ser afetado, é necessária uma análise ponderada considerando necessariamente o terceiro subprincípio da proporcionalidade. Se o ato $\mathrm{L}_{1}$ é praticado para realizar o princípio $\mathrm{P}_{1}$, mas interfere na efetivação ou colide com o princípio $\mathrm{P}_{2}$, e ao mesmo tempo tem-se o ato $\mathrm{L}_{2}$, que consegue promover com igual eficiência $\mathrm{P}_{1}$, mas sem limitar $\mathrm{P}_{2}, \mathrm{~L}_{1}$ deve ser afastado em razão da possibilidade de $\mathrm{L}_{2}$. O Poder Judiciário, por meio dos seus atos interpretativos e de certa discricionariedade, pode definir, independentemente das vontades do Legislativo e da sociedade, que uma lei ou ato administrativo seja invalidado e declarado inconstitucional por não atingir de forma eficiente os objetivos que pretende alcançar ao interferir em outros objetivos de interesse público, possibilitando que outro ato ou lei seja aplicado em seu lugar.

O último subprincípio é a proporcionalidade em sentido estrito, que consiste no sopesamento entre princípios. Parte-se de uma análise da intensidade do ato praticado ou da lei promulgada, sopesando e comparando o direito fundamental atingido e a importância da efetivação do direito fundamental objetivado pelo ato legislativo ou executivo. Alexy resume esse subprincípio na seguinte regra: "quanto maior o grau de não-satisfação ou detrimento de um princípio, maior deve ser a importância da satisfação do outro" (ALEXY, 2014, p.14).

Esses atos não precisam inviabilizar ou limitar completamente um direito fundamental para que sejam afastados pelo Judiciário. Basta que a motivação da lei ou do ato administrativo não tenha o "peso" necessário que justifique a restrição de outro direito fundamental. O termo peso carrega em si um sentido objetivo, pois se trata de uma medida padronizada em relação a um referencial. Contudo, nesse caso, o peso é definido pelo intérprete que o determina discricionariamente.

Existem três variáveis na fórmula de peso: a) o grau de envolvimento dos princípios no caso específico; b) o peso abstrato dos princípios envolvidos; c) a segurança dos resultados que as medidas irão gerar (ATIENZA, 2014, p.13). Robert Alexy atribui valores a essas variáveis. As duas primeiras possuem três níveis: leve, médio e pesado; a terceira, por sua vez, pode ser classificada como segura, plausível ou não evidentemente falsa. Assim, se a restrição do direito possui um peso médio e ainda pode ser perfeitamente realizada, mas o peso do direito que fundamenta essa restrição é leve, o ato é desproporcional. Nos casos em que há empate, quando desse "cálculo" resultam pesos idênticos entre os princípios, cabe ao intérprete estabelecer uma prioridade em favor da liberdade e em favor da constitucionalidade da lei (ATIENZA, 2014, p.13). A decisão cabe integralmente aos intérpretes, que devem manter um grau de adequação 
ao sistema jurídico e sua tradição (SILVA, 2002, pp. 27-28), o que, segundo nos parece, remete exatamente às noções de liberdade-privilégio, eis que não estamos falando de sistemas abstratos, mas sim de sistemas político-econômicos de matriz liberal-capitalista.

Essas técnicas e formas de fundamentação das decisões usadas pelo Poder Judiciário em casos que permitem mais de uma decisão correta operam como um controle de racionalidade das decisões. A regra mencionada, segundo a qual "quanto maior o grau de descumprimento ou de interferência em um princípio, maior deve ser a importância do outro princípio" (ALEXY, 2014b, p. 192), indica que mediante essa ponderação o juiz, lançando mão de seus valores individuais ou dos interesses de classe que reproduz e representa às vezes de maneira até mesmo inconsciente, decide sobre a suspensão parcial de determinado direito fundamental positivado diante da necessidade de efetivar outro que julga mais "pesado".

É nesse sentido que a crítica de Juan Antônio de Garcia Amado se delineia. O autor mostra que a técnica da ponderação se aproxima muito mais do ato de sopesar do que do ato de pesar, já que este apresenta critérios objetivos, enquanto aquele tem como traço a subjetividade (GARCÍA AMADO, 2014, p. 50).

Garcia Amado faz uma interessante comparação com objetos materiais e demonstra que ao pesar um lápis ou uma caneta tem-se seu peso exato, sendo que uma contestação sobre os resultados tem que se basear na qualidade da balança ou na forma como foram pesados (ou seja, nos dados objetivos). Por outro lado, o sopesamento ocorre quando não se tem a possibilidade de pesar o objeto com uma balança, com objetividade referencial, havendo interesse em saber seu peso relativo. Assim, o sujeito usa sua noção subjetiva para adivinhar o dado objetivo - no caso, se a caneta é mais ou menos pesada que o lápis. O sopesamento é o resultado de uma incapacidade de obter um resultado objetivo; abre-se mão do rigor sobre os dados e se realiza um julgamento aproximado, de acordo com a visão do agente que imagina a pesagem. Não há qualquer garantia de acerto e é inclusive possível entender pesos próximos como corretos ou correspondentes (GARCÍA AMADO, 2014, p. 50). A contestação a respeito do sopesamento e seu resultado pode se referir aos critérios, ao valor a que se chegou e à relação desse peso com outros sopesados anteriormente, sem que seja possível conferir ou aferir o resultado da pesagem.

Os objetos imateriais, como princípios ou direitos, não possuem peso em si. Pelo contrário, o peso é atribuído pelos sujeitos que medem a importância do valor ou do princípio. O sopesamento é realizado de acordo com os critérios subjetivos dos sujeitos e os critérios, por 
sua vez, são definidos pelas condições pessoais do agente: raça, classe, gênero, sexualidade, dentre outros, sendo impossível um agente se distanciar de seus valores e racionalidade para utilizar supostos valores universais e racionalidade "neutra". Se objetos materiais permitem mensuração posterior para que seja apurada a diferença de peso entre eles e o sopesamento realizado pelos agentes, o mesmo não pode ser feito com ideias ou princípios, seja em abstrato ou em comparações concretas. A moral e os valores de cada pessoa fazem com que ela tenha percepções diferentes sobre os mesmos fatos, não sendo possível indicar se tal está certo ou errado.

Uma pequena história que serve para ilustrar o exposto seria a de um sujeito que tem uma oportunidade de emprego estável e financeiramente vantajosa em outro país, mas teria que deixar para trás sua noiva que, por razões pessoais, não poderia sair do Brasil. Ou, em vez de abandonar a noiva, o tal sujeito teria de deixar o novo curso de Letras que começou e sempre quis fazer. O sujeito fica dividido diante da ausência de perspectivas em sua área e de ter que abrir mão de um relacionamento ou do seu sonho de estudar literatura. A propensão de uma pessoa que possui privilégios econômicos e não necessita nem nunca necessitou vender sua mão-de-obra para sobreviver a escolher a oportunidade profissional é, evidentemente, muito menor do que de uma outra que sempre teve que vender sua força de trabalho para garantir seus meios de subsistência. Ambas as pessoas entendem de forma diferente o trabalho e o lugar que ele ocupa em suas vidas. As escolhas e os valores dos privilegiados e seu sopesamento tendem a diferir da maioria desprivilegiada. Analisando os agentes que realizam o sopesamento judicial, é possível perceber que a subjetividade de uma classe, ou seja, de um grupo uniforme de pessoas privilegiadas que exercem o poder, é a chave de interpretação do sopesamento. Tal grupo determina e define a lógica por trás da ponderação e da interpretação judicial (GARCÍA AMADO, 2014, p. 54). A unidade de classe dos juízes pode ser percebida no Brasil onde, de acordo com o censo judiciário, tal classe tem 65\% de homens (BRASIL, 2014, p. 37) e 84\% de brancos, sendo que nos tribunais superiores, nos quais o ato interpretativo possui mais poder, esse percentual sobe para 91\% (BRASIL, 2014, p. 42). Apenas 1\% tem uma relação homoafetiva estável, seja casamento ou união estável, número que sobe para $78 \%$ quando consideradas relações heterossexuais estáveis (BRASIL, 2014, p. 47).

O juiz-intérprete, ao ponderar princípios, não descobre seu peso, mas cria-o e, por meio do procedimento descrito nas páginas anteriores, justifica sua decisão sobre qual será o princípio que prevalecerá no caso concreto. Assim, ele cria uma nova determinação que deve 
ser aplicada ao caso concreto, mas também se estende e guia outras interpretações. $\mathrm{Na}$ sequência, serão utilizados dois casos brasileiros a fim de explicitar a aplicação das técnicas de ponderação. Primeiro, o Habeas Corpus n ${ }^{\circ} 126.292$ (HC 126.292) e posteriormente o Habeas Corpus $\mathrm{n}^{\circ} 141.949$ (HC141.949).

O HC 126.292 foi impetrado no STF em 15 de janeiro de 2015, tendo o paciente questionado a constitucionalidade da decretação de sua prisão em segunda instância - portanto, antes do trânsito em julgado, que se entende como a decisão final de um processo, depois da qual não se permite mais a interposição de recursos com capacidade modificativa, seja em função do esgotamento dos prazos para a interposição dos recursos cabíveis ou pelo exaurimento das vias recursais possíveis. A jurisprudência do STF sustentava até então entendimento de que a prisão só poderia ser decretada após o trânsito em julgado da sentença penal condenatória, considerando a literalidade Constituição Federal em seu art. $5^{\circ}$, inciso LVII:

Art. $5^{\circ}$ Todos são iguais perante a lei, sem distinção de qualquer natureza, garantindo-se aos brasileiros e aos estrangeiros residentes no País a inviolabilidade do direito à vida, à liberdade, à igualdade, à segurança e à propriedade, nos termos seguintes:

LVII - ninguém será considerado culpado até o trânsito em julgado de sentença penal condenatória; (BRASIL, 1988)

Além da Constituição, a jurisprudência da corte considerava a Convenção Americana de Direitos Humanos, ou seja, o Pacto de San José da Costa Rica, que prevê em seu art. $8^{\circ}$ que "Toda pessoa acusada de um delito tem direito a que se presuma sua inocência, enquanto não for legalmente comprovada sua culpa" (BRASIL, 1992). Ainda nesse sentido, o Código de Processo Penal determina em seus artigos 283 e 675:

Art. 283. Ninguém poderá ser preso senão em flagrante delito ou por ordem escrita e fundamentada da autoridade judiciária competente, em decorrência de sentença condenatória transitada em julgado ou, no curso da investigação ou do processo, em virtude de prisão temporária ou prisão preventiva.

Art. 675. No caso de ainda não ter sido expedido mandado de prisão, por tratarse de infração penal em que o réu se livra solto ou por estar afiançado, o juiz, ou o presidente da câmara ou tribunal, se tiver havido recurso, fará expedir o mandado de prisão, logo que transite em julgado a sentença condenatória (BRASIL, 1941).

A literalidade do conjunto normativo indica com certa nitidez que o trânsito em julgado é necessário para que uma pessoa seja considerada culpada e comece a sofrer as consequências da sentença penal condenatória, dentre elas a reclusão. O conjunto normativo regula as 
exceções, delineando que em casos de flagrante delito ou de prisão temporária ou preventiva (nenhum deles presente no caso do habeas corpus em exame), a pessoa poderá ser presa cautelarmente, sem desrespeito ao conjunto normativo. O poder legislativo compreendeu que esses são os casos de exceção à garantia da presunção de inocência. O STF, no entanto, mudou seu entendimento - desde 2009 prevalecia na corte que a prisão somente poderia ser decretada após o trânsito em julgado de sentença condenatória, quando foi julgado o habeas corpus $\mathrm{n}^{\circ}$ 84.078/MG - e determinou a possibilidade de cumprimento antecipado da decisão condenatória em segundo grau, ou seja, mediante o julgamento dos tribunais, com a prisão do réu ainda, que ele não possa ser declarado culpado.

Nesse julgamento, Robert Alexy foi nominalmente citado pelo Ministro Luís Roberto Barroso quando proferiu seu voto, afirmando que a presunção de inocência deveria ser "realizada na maior medida possível, dentro das possibilidades jurídicas e reais existentes". A partir do conceito de "princípio" de Alexy, o Ministro Barroso conclui, nas páginas 12-13 do seu voto (BRASIL, 2016), que a presunção de inocência não é uma regra que deve ser subsumida ao caso concreto, mas um "mandado de otimização, caracterizado pelo fato de que pode ser cumprido em diferentes graus", e que deve ser determinada e medida em âmbito jurídico "pelos princípios e regras opostas". Barroso passa, então, a "ponderar" o princípio da presunção de inocência "com os outros objetivos e interesses em jogo".

Assim, o Acórdão do STF, especialmente o voto de Barroso, tensiona o princípio da presunção de inocência, presente no art. $5^{\circ}$, LVII, da Constituição Brasileira, e indica que a sua máxima efetividade significaria que nenhum efeito da sentença penal condenatória pudesse ser aplicado ao acusado até que ocorresse o trânsito em julgado. Contudo, argumenta Barroso, o ordenamento jurídico brasileiro não entende tal hipótese como uma máxima absoluta, fazendo relativizações e abrindo espaço para possíveis exceções. Portanto, esse princípio deve ser ponderado com a efetividade da lei penal, que tem como objetivos a prevenção geral e específica (desestimular atos delituosos da sociedade e do sujeito, respectivamente) e a proteção aos bens jurídicos (vida, dignidade humana, propriedade etc.) tutelados pela esfera penal. Notese que tais ideias que não estão expressas de forma taxativa na Constituição, ao contrário da regra da presunção de inocência, mas podem ser deduzidas dos princípios da razoável duração do processo e da segurança.

Segundo Barroso, os artigos do Código de Processo Penal acima mencionados, principalmente o art. 283, expõem a necessidade e a autorização da ponderação, haja vista as 
mencionadas exceções previstas, quais sejam, prisão temporária, preventiva e prisão decorrente de flagrante delito. A relativização interna realizada pelo próprio ordenamento jurídico resultaria na possibilidade da prisão após a condenação em segundo grau, sem trânsito em julgado. Para o Ministro neoconstitucionalista, a lei não pode abrir exceções e depois ser interpretada de forma absoluta. Além do mais, os princípios constitucionais citados levariam a uma relativização da própria norma. Nas palavras de Barroso, na página 14 do seu voto (BRASIL, 2016), "acentue-se, porque relevante: interpreta-se a legislação ordinária à luz da Constituição, e não o contrário". Ora, é o que ele próprio não parece ter feito, dado que as exceções à prisão antes do trânsito em julgado são buscadas na legislação infraconstitucional para justificá-la em caráter geral, inserindo uma exceção não-legal na dimensão constitucional.

Ainda segundo Barroso, a interpretação constitucional das normas e do caso concreto em debate indica que o "peso" do princípio da presunção de inocência é proporcional à fase do processo em que a decisão é proferida, ou seja, é reduzido com o passar das fases processuais, com as seguidas confirmações materiais da autoria e da existência do ato delituoso. Assim, a presunção de inocência possuiria um peso maior na fase pré-processual, o que seria reduzido com a constante confirmação da prática do ilícito até que ela se extinga com o trânsito em julgado. Além disso, Barroso entende que deve ser considerado o peso do princípio da eficácia penal, principalmente diante das estatísticas que evidenciam a pouca chance de sucesso na reversão de decisão condenatória em sede de Recursos Especial e Extraordinário, recursos que permitem o julgamento do caso pelo STJ e pelo STF, principalmente porque esses tribunais não podem reanalisar fatos e provas, reformando apenas questões de direito. Dessa forma, o Ministro enxerga o peso da presunção de inocência como mais leve do que o peso da efetividade e da credibilidade judicial, e assim conclui na página 15 do seu voto:

Portanto, o sacrifício que se impõe ao princípio da não culpabilidade - prisão do acusado condenado em segundo grau antes do trânsito em julgado - é superado pelo que se ganha em proteção da efetividade e da credibilidade da Justiça, sobretudo diante da mínima probabilidade de reforma da condenação, como comprovam as estatísticas. Essa conclusão é reforçada pela aplicação do princípio da proporcionalidade como proibição de proteção deficiente. (BRASIL, 2016)

No Acórdão, o STF entendeu que a determinação constitucional, a tradição jurídica ocidental e a letra da lei - o art. 283 do Código de Processo Penal - não eram válidos diante do seu ato interpretativo. Decidiu assim por suspender as normas e nesse vácuo criar uma nova determinação, “em outras palavras, não há regras (incluindo normas constitucionais de direitos 
fundamentais, como as que estão em jogo aqui) com um conteúdo essencial ou um núcleo capaz de prever a solução para casos futuros" (GARCÍA AMADO, 2014, p. 52). Trata-se, inequivocamente, de uma exceção interpretativa soberana, dado que não pode ser revisada por nenhum outro órgão da República.

O Ministro Gilmar Mendes chegou a conclusão distinta, entendendo que a presunção de inocência é um preceito que já tem suas mitigações previstas na lei ordinária. Portanto, não seria impossível uma ponderação que reconhecesse a presunção de inocência como um dos princípios máximos do Estado de Direito, haja vista o caráter extremo da restrição da liberdade e a ideia de que mitigar o poder do Estado de interferir na liberdade das pessoas é um dos fundamentos primordiais do direito ocidental. Essa possibilidade é completamente crível, pois o sopesamento abre a oportunidade para que cada um "pese" o objeto de forma distinta, o que revela o fato decisivo: não são os princípios que pesam mais ou menos ou as circunstâncias do caso que dão pesos aos princípios, mas sim os sujeitos que têm poder para tanto.

O segundo julgado é o HC 141.949 impetrado no STF em 23 de março de 2017. O paciente questionou a constitucionalidade do artigo 299 do Código Penal Militar, que tipifica o crime de desacato a militar - “Art. 331 - Desacatar militar no exercício da função ou em razão dela: Pena - detenção, de seis meses a dois anos, se o fato não constitui outro crime" (BRASIL, 1969). O paciente fundamentou seu pedido na violação do art. 13 da Convenção Americana de Direitos Humanos e dos arts. 5º, IV, V e IX e 220 da Constituição Federal, ou seja, garantia fundamental à liberdade de expressão e ao livre pensamento:

Artigo 13. Liberdade de pensamento e de expressão.

Toda pessoa tem direito à liberdade de pensamento e de expressão. Esse direito compreende a liberdade de buscar, receber e difundir informações e idéias de toda natureza, sem consideração de fronteiras, verbalmente ou por escrito, ou em forma impressa ou artística, ou por qualquer outro processo de sua escolha. (BRASIL, 1992)

Art. $5^{\circ}$ Todos são iguais perante a lei, sem distinção de qualquer natureza, garantindo-se aos brasileiros e aos estrangeiros residentes no País a inviolabilidade do direito à vida, à liberdade, à igualdade, à segurança e à propriedade, nos termos seguintes:

IV - é livre a manifestação do pensamento, sendo vedado o anonimato;

$\mathrm{V}$ - é assegurado o direito de resposta, proporcional ao agravo, além da indenização por dano material, moral ou à imagem;

IX - é livre a expressão da atividade intelectual, artística, científica e de comunicação, independentemente de censura ou licença; 
Art. 220. A manifestação do pensamento, a criação, a expressão e a informação, sob qualquer forma, processo ou veículo não sofrerão qualquer restrição, observado o disposto nesta Constituição (BRASIL, 1988).

A Segunda Turma do STF aproveitou a oportunidade para também analisar a constitucionalidade do art. 331 do Código Penal que prevê o crime de desacato simples, diante da similitude entre os tipos penais: "Desacatar funcionário público no exercício da função ou em razão dela: Pena - detenção, de seis meses a dois anos, ou multa" (BRASIL, 1940).

O Ministro relator Gilmar Mendes indicou que a discussão se centraliza na ponderação de direitos fundamentais, de um lado a liberdade de expressão, prevista pela Convenção Interamericana de Direitos Humanos - CIDH e pela Constituição, e do outro o direito à honra, intimidade e dignidade, devendo o intérprete buscar a conciliação entre as normas constitucionais (BRASIL, 2018, p. 10). O relator remete aos seus escritos doutrinários a fim de indicar a técnica que utilizará para encontrar uma solução proporcional ao problema:

Os problemas de concordância prática surgem, sobretudo, em casos de colisão de princípios, especialmente de direitos fundamentais, em que o intérprete se vê desafiado a encontrar um desfecho de harmonização máxima entre os direitos em atrito, buscando sempre que a medida de sacrifício de um deles, para uma solução justa e proporcional do caso concreto, não exceda o estritamente necessário (MENDES, 2017, p. 94-95).

Gilmar Mendes indica a importância do direito fundamental à liberdade de expressão no regime democrático que protege a pluralidade de opiniões, e conclui em sentido oposto argumentando que a "repressão do excesso não é incompatível com a democracia" (BRASIL, 2018, p. 12). Com efeito, a real questão de fundo não é o já conhecido embate entre excessos da liberdade de expressão e os direitos de personalidade como honra, intimidade e dignidade. O questionamento levantado pelo paciente recai sobre a maior proteção que os agentes públicos e especialmente os militares possuem em relação à sua honra frente aos outros cidadãos, bem como a incompatibilidade dessa proteção com a democracia e o princípio republicano.

Mendes argumenta que tal proteção não é um privilégio, mas uma regra de proporcionalidade diante das maiores obrigações que recaem sobre os funcionários públicos. Além disso, indica que a criminalização do abuso de poder produz um equilíbrio no ordenamento, que também pune os atos excessivos dos agentes, mantendo o prestígio do princípio do interesse público. O relator indica que havendo lei, "ainda que deficitária, punindo o abuso de autoridade (Lei 4.898/65), pode-se afirmar que a criminalização do desacato se mostra compatível com o Estado Democrático de Direito" (BRASIL, 2018, p. 12). 
Assim como no caso anterior, quando dois princípios jurídicos e/ou direitos humanos fundamentais colidem, a resposta é a manutenção e o fortalecimento da máquina repressiva do Estado. Assim, paradoxalmente, a ampliação do Estado e de sua força resolveria o excesso de violência criado e praticado pelo próprio Estado. Os Ministros Luís Roberto Barroso, Dias Toffoli e Ricardo Lewandowski acompanharam o voto do relator.

Por seu turno, o Ministro Edson Fachin foi voto vencido e realizou uma remissão aos julgados da Corte Interamericana de Direitos Humanos ao analisar os princípios e os direitos fundamentais em embate. Fachin aponta que uma série de convenções e declarações da Comissão Interamericana de Direitos Humanos indicam que:

a penalização de qualquer tipo de expressão só pode aplicar-se em circunstâncias excepcionais nas quais exista uma ameaça evidente e direta de violência anárquica e que, por isso, a proteção especial que as leis de desacato dão aos funcionários públicos contra uma linguagem insultante ou ofensiva é incongruente com o objetivo de uma sociedade democrática de fomentar o debate público. [...] As leis que punem a expressão ofensiva contra funcionários públicos, geralmente conhecidas como "leis de desacato", atentam contra a liberdade de expressão e o direito à informação (BRASIL, 2018, p. 19).

Fachin também recorre ao uso da técnica da proporcionalidade para fundamentar sua posição baseada no entendimento da Corte Interamericana: "é por meio de um juízo de proporcionalidade que se pode aferira incompatibilidade das leis de desacato com a Convenção" e seus princípios e direitos fundamentais. O Ministro complementa que a análise desse argumento de proporcionalidade "parte do pressuposto de que não há direitos absolutos e que os direitos fundamentais, desde que se atenda a um fim legítimo, podem ser limitados" (BRASIL, 2018, p. 19), antes de concluir de forma contrária aos outros Ministros.

Sopesando o princípio republicano, o princípio democrático e o direito à liberdade de expressão com o princípio do interesse público, Fachin asseverou que os crimes de desacato são incompatíveis com a Constituição Federal de 1988. Apesar do voto proferido por Edson Fachin e das inúmeras decisões da Corte Interamericana de Direitos Humanos, o vago princípio do "interesse público" foi capaz de afastar o direito humano fundamental à liberdade de expressão, devidamente suspenso de maneira exceptiva para que o Estado não reduza os mecanismos de repressão "compatíveis" com a democracia.

A decisão não revela apenas a suspensão da liberdade de expressão, sopesada e mitigada, conforme indica a teoria da proporcionalidade. $\mathrm{O}$ julgado também importa na suspensão de normas da Convenção Americana de Direitos Humanos e da Declaração de 
Princípios Sobre Liberdade de Expressão para manter o poder violento e repressivo do Estado. É importante indicar que as convenções e os tratados compõem a base normativa do bloco de constitucionalidade do Brasil, devendo ser analisados não apenas como recomendações, mas verdadeiras normas.

A análise das decisões do STF que recorrem ao sopesamento confirmam a crítica de García Amado, Matos e Souza. A técnica não analisa o peso dos princípios, apenas possibilita que diante das circunstâncias fáticas o julgador-intérprete, agente do poder público, recorra ao seu poder justificando e determinando o peso de casa princípio e ofereça outra norma para a solução do caso concreto.

A técnica da ponderação desenvolvida por Alexy e empregada pelos tribunais na realização de interpretações constitucionais gera uma nova forma normativa, de feição puramente exceptiva. A norma completa, $\mathrm{N}$, deixa de ser enunciada pela fórmula se $F$ é, $S e ́$ permitido/proibido/ordenado, e passa então a ser se Fé, $S$ é permitido/proibido/ordenado, a menos que exista alguma motivação para que o intérprete, no caso específico, pondere sobre um princípio e ofereça outra norma (GARCÍA AMADO, 2014, p. 54). Outra possibilidade, mais simples e direta seria dizer: a menos que o soberano decida sobre a exceção. Juan Antonio García Amado conclui que, como consequência do uso dessa técnica interpretativa, que "os direitos, os tão alardeados direitos que seriam a essência desse modelo de Estado constitucional, tornam-se rigorosamente provisórios, mesmo quando há uma norma legal que os desenvolve tentando maximizar (ou otimizar) seu escopo" (GARCÍA AMADO, 2014, p. 70).

A teoria constitucional ordinária ensina que o legislador, além de possuir legitimidade democrática para a produção normativa, produz leis que são abstratas, incorporando exceções específicas quando pretende ajustar a norma às condições materiais ou aos valores sociais. Assim, o número de exceções possíveis ou de limitações para cada regra é finito e previamente conhecido. O juiz, com base na ponderação, excede essa moldura. Ele excede a regra que marca a exceção à regra; ao suspender o direito, ele suspende a norma e a desloca para fora do campo jurídico. Dessa forma, abre-se um espaço em que o juiz é livre para criar outra norma, incluindo novamente a primeira ao referenciá-la somente para suspendê-la outra vez em sua decisão. O legislativo e sua produção legiferante são assim controlados, nos termos e condições excepcionais explicitados. É nesse sentido que o controle de constitucionalidade se revela como controle sobre o "perigo" democrático que, mesmo extremamente mitigado pela representação política, ainda se mostra muito perigoso para o projeto liberal e elitista de Estado. 
A técnica da ponderação é uma decorrência da usurpação pelo Judiciário do poder de criação normativa típico do Legislativo, protegendo ou restringindo direitos apenas de uma parte da população. O juiz-intérprete deve, portanto, fundamentar por meio da "racionalidade" a não aplicação de uma norma e a criação normativa que executa em um procedimento próprio e específico. "Racionalidade", nesse contexto, é o respeito às normas que informam o método da proporcionalidade, a ser executado pelo juiz quando exerce o ato interpretativo-decisório. No entanto, a própria demarcação de o que é um processo decisório racional ou irracional já é uma decisão, anterior e externa ao ordenamento jurídico. A teoria de Alexy, ao tentar definir o que é uma decisão racional por meio de outra decisão, é tautológica, "pois o termo 'racionalidade' e o termo 'decisão' representam o mesmo ideal, ainda que de maneiras diferentes" (MATOS; SOUZA, 2017, p. 303).

Assim, Alexy busca fundamentar conteúdos jurídicos mediante conteúdos jurídicos, dado que as técnicas de interpretação constitucional, tanto a da proporcionalidade quanto a da argumentação racional, são regras procedimentais, ou seja, "conteúdos jurídicos mínimos capazes de guiar a atividade interpretativa" (MATOS; MILÃO, 2013, p. 132) que têm por função declarar os valores que serão otimizados e aqueles que serão relativizados. No entanto, esses conteúdos jurídicos mínimos partem dos mesmos valores do sistema jurídico intuídos pelo intérprete - racionalidade, igualdade, liberdade, participação, dentre outros -, os quais o intérprete pretende declarar como válidos e otimizar. Novamente a teoria de Alexy recorre a uma tautologia para fundamentar seu procedimento. Se a teoria da argumentação e a proporcionalidade são conjuntos de "normas para a justificação de normas" (ALEXY, 1983, p. 225), o fundamento do sistema está confirmado a priori no próprio método. Alexy parte de um sistema normativo para fundamentar outro sistema normativo, sendo que ambos compartilham os mesmos conteúdos e valores. As normas que serão justificadas são o fundamento das normas procedimentais justificadoras. Trata-se apenas de um processo tautológico de confirmação dos dados dos quais já se parte. Assim, o que se busca é revelar os fundamentos dos princípios com base nos conteúdos jurídicos mínimos, que têm como embasamento esses mesmos fundamentos, e confirmá-los mediante a interpretação judicial.

Pois bem, esse conjunto tautológico de procedimentos e de normas de validação são a hipotética inovação do neoconstitucionalismo e do novo interpretativismo jurídico. Dimoulis, mais uma vez, demonstra que não há grande novidade nisso: 
a opção metodológica e a prática de recurso a princípios e outros elementos normativos caracterizados pela vagueza não apresentam o menor traço de inovação. Na história do direito ocidental, muitas são as referências teóricas e as práticas de interpretação flexível, casuística, criativa e até mesmo livre do direito. Basta pensar em termos tais como direito pretoriano, equidade, espírito da lei, analogia, direito livre para entender que a importância dada aos princípios jurídicos e ao papel-poder criativo do aplicador não constitui novidade (DIMOULIS 2008, p. 12).

O autor faz remissão direta ao constitucionalismo do século XIX, no seio do qual havia forte produção teórica crítica à aplicação literal e maquinal das leis. Inclusive, alguns juristas indicam que o aplicador, principalmente o juiz, possuía competência legislativa a fim de resolver os conflitos sociais. ${ }^{11}$ Mas essa análise pode ser expandida tendo em vista toda a história do direito ocidental, que revela uma tradição interpretativa com uma conhecida capacidade de criação normativa em períodos anteriores ao século XVIII. Autores como Ludovico Antônio Muratori (1672-1750), Alessandro Verri (1741-1816) e Pietro Verri (17281797) criticavam as práticas judiciais das quais eram contemporâneos. Registraram, assim, o abuso criativo dos juízes em seus atos interpretativos, enquanto sustentavam uma visão que opunha lei e interpretação. Pietro Costa chama esses autores e o grupo a que pertencem de reformadores radicais e indica que eles eram "perfeitamente conscientes do valor (que um teórico oito-novecentista chamará de) ‘criativo’ da interpretação” (COSTA, 2016, p. 746). Eles viam o ato interpretativo como algo negativo, ou seja, como a usurpação por parte do Judiciário do poder legiferante típico do Legislativo. O historiador e jurista italiano continua com seu registro e evidencia esse processo de forma elucidativa:

o juiz não pode ser, por sua vez, legislador; mas ele se torna tal se é deixado livre para interpretar a lei. Interpretar, de fato, significa, como escreve Pietro Verri, "apropriar-se do lugar de quem escreveu a lei", significa fazer o legislador dizer mais do que ele disse, e esse mais é a medida da faculdade legiferante que se arroga o juiz (COSTA, 2016, p. 746).

Além da interpretação criativa enquanto característica da atuação do Poder Judiciário ao longo dos séculos, suposta novidade do neoconstitucionalismo, está presente no pensamento dos séculos XVII e XVIII uma preocupação com a potência legiferante dos juízes. Os iluministas entendiam que o poder de criação normativa era exclusivo do soberano, seja na

${ }^{11}$ Dimoulis (2008, p. 12) cita os seguintes autores e obras como referência ao mencionado posicionamento: Oskar Bülow (1837-1907), Gesetz und richteramt, 1885, na Alemanha; François Gény (1861-1959), Méthode d'interprétation et sources en droit privé positis, 1889, na França e Eugen Ehrlich (1862-1922) Freie Rechtsfindung und freie Rechtswissenschaft, 1903, na Áustria. 
figura do Rei ou do Parlamento (COSTA, 2016, p. 750), e vaticinam que a usurpação desse poder gera grande instabilidade e insegurança no ordenamento jurídico. O contexto da dinâmica entre lei e interpretação que pode ser percebido hoje é muito semelhante ao iluminista: a interpretação, somada ao extenso conjunto normativo, resulta em poder excessivo e excepcional dos juízes-intérpretes, gerando arbitrariedade e incerteza. Se hoje a técnica interpretativa é a ponderação, no contexto iluminista era a equidade, caracterizada como um dos principais veículos da desordem, dado que a equidade "sempre quer dizer arbítrio, e arbítrio quer dizer nenhuma lei" (COSTA, 2016, p. 745). Equidade e ponderação são vistas, cada uma em seu tempo, como o domínio da aleatoriedade e da incerteza, capazes de transformar a exceção em regra.

É interessante perceber que o excesso interpretativista gerou nos iluministas uma paradoxal percepção do risco de anomia surgido da criação normativa. A arbitrariedade dos juízes-intérpretes gerava um vazio normativo no qual as leis perdiam o sentido e a força que possuíam, enfraquecida diante da constante inversão entre regra e exceção. É claro que no contexto iluminista não há uma prototeoria do estado de exceção; seria de um anacronismo assombroso indicar qualquer percepção nesse sentido. Trata-se apenas de uma noção semelhante quanto aos efeitos produzidos pela interpretação arbitrária dos agentes do Poder Judiciário. Encontram-se presentes, no iluminismo do século XVIII e no constitucionalismo do século XIX continuidades com o supostamente inovador movimento neoconstitucionalista, que afirma "pela enésima vez a antiga tese segundo a qual os órgãos jurisdicionais são os guardiões naturais do direito e dos direitos" (COSTA, 2010, p. 254).

Apesar de também haver um variado quadro de descontinuidades, a tradição continua reafirmando a velha hipótese de que o caráter lógico-racional da interpretação judicial e a razão imparcial e objetiva do juiz seriam capazes de dar uma melhor interpretação às normas e controlar os abusos potestativos do povo, representado pelo soberano. Nessa perspectiva, o juiz perde a dimensão de poder neutro e imparcial, assumindo um caráter ativo e político a cada "interpretação-aplicação do direito", de modo que a desejada posição de "razão técnica" se traduz cada vez mais em protagonismo político. Assim, a lógica da participação e do consenso, já despotencializada pela mediação do voto e da representação, passa a ser ainda mais reduzida pela decisão técnica e "moralmente" capaz dos juízes-intérpretes. O iluminismo indicava, em decorrência da legitimação democrática do poder, que essas decisões tinham que ser tomadas pelo legislativo ou pelo príncipe. A tradição interpretativa, por outro lado, vê o juiz como 
responsável por esse papel, devido à sua natureza pretensamente neutra, imparcial e sábia. Segundo Dimitri Dimoulis, essa atuação parece estar mais ativa do que nunca (DIMOULIS, 2008, pp. 6-11). Embora o neoconstitucionalismo não evoque nenhuma grande novidade, ele configura a retomada de uma tradição antipositivista e antilegalista caracterizada por recorrer a elementos externos ao direito a fim de direcionar a sua compreensão e modulação.

Ciente das críticas à tradição interpretativista, os neoconstitucionalistas incorporam os elementos antes externos ao ordenamento, mas deixam o seu conteúdo aberto à interpretação dos agentes. Os elementos incorporados são os mais diversos, todos definidos pelos juízesintérpretes diante dos casos concretos, com a proporcionalidade e a moral assumindo um acentuado protagonismo. Os juízes subtraem para si a competência das decisões políticas do legislador, com a consciência de que a prática resulta na concentração de poderes nas mãos de um único corpo - o judicial (POZZOLO, 1998).

Dessa forma, os conflitos sociais são transformados em lides com a judicialização da vida, e normatizados mediante decisões "moralmente corretas" do juiz (ALEXY, 2014b, p.14), ou seja, aquelas que podem ser racionalmente fundamentadas segundo seus valores e "pesos". A conexão entre moral e direito se dá por meio do desdobramento deste em uma "moral universalística procedimental" (ALEXY, 2014b, p.14) que, como observado, já é regida por normas morais previamente escolhidas a partir de decisões anteriores que definem os conteúdos que irão determinar o procedimento jurídico de sopesamento. Assim, o direito moralizado de forma a priori por Alexy se desdobra em si mesmo, haja vista que as fundamentações de suas decisões se ligam a valores morais escolhidos por uma decisão prévia (MATOS; SOUZA, 2017, p. 304). Por isso mesmo o método de Alexy admite que decisões que violam a ordem jurídica podem ser consideradas corretas desde que obedeçam aos procedimentos argumentativos e ponderativos, ou seja, desde que sejam racionalmente justificadas: “Alexy normatiza o discurso jurídico estabelecendo regras que ele mesmo desenvolveu como método para se chegar a uma argumentação que justifique moralmente certa decisão judicial” (MATOS; SOUZA, 2017, p. 304).

É nesse contexto que o Poder Judiciário se sente livre e se anuncia como agente legítimo para assumir protagonismo na vida pública e política. Os conceitos de judicialização da vida e de ativismo judicial são utilizados para indicar essa interpretação protagonista que o Poder Judiciário exerce, governando mediante suas decisões a vida política e social da comunidade. Com efeito, os conceitos de judicialização e de ativismo judicial são duas faces da mesma 
moeda. A judicialização é uma consequência do constitucionalismo, representando o cumprimento do projeto constitucional liberal com o empoderamento do Judiciário e envolvendo uma transferência (in)constitucional de poder. O Judiciário deixa assim de ser um poder apenas técnico-especializado e se transforma em um poder político, evocando as competências dos poderes representativos.

Por seu turno, o ativismo jurídico corresponde à escolha política dos juízes em interpretar a Constituição de modo proativo, estendendo seu alcance e sentido para áreas não indicadas expressamente pelo constituinte (BARROSO, 2012, pp. 23-25). Para Luís Roberto Barroso, o ativismo jurídico se manifesta de três formas: a) a aplicação da Constituição de maneira direta em situações não previstas expressamente em seu texto e sem depender de qualquer ação ou provocação do Poder Legislativo; b) a aplicação de critérios não previstos constitucionalmente ou resultantes de interpretações normativamente criadoras de dispositivos constitucionais no controle de constitucionalidade dos atos normativos do Legislativo; c) a determinação ao poder público que pratique ou se abstenha de praticar atos relativos às políticas públicas. Vê-se assim que o ativismo judiciário também amplia o protagonismo judicial nas relações políticas e sociais. De fato, os juízes invocam a missão constitucional de “concretização dos valores e fins constitucionais" (BARROSO, 2012, p. 26) para interferirem além dos limites constitucionalmente previstos. Trata-se então do uso da Constituição para a suspensão parcial da Constituição, para que a norma seja suspensa e nesse vazio normativo anômico e exceptivo o Judiciário crie normas por meio de decisões judiciais com força de lei.

Apesar das diferenças entre ativismo judicial e judicialização, os dois movimentos denotam a expansão do sistema judicial com a invasão das esferas representativas do Estado. O Judiciário evoca o poder de decidir politicamente, com a consolidação da prática na atualidade. A justificativa racional retoricamente apresentada para tanto é uma estratégia para velar a natureza autoritária da decisão judicial que apenas se realiza mediante a violência que funda e mantém a ordem constitucional ativa (COVER, 1985-1986).

\section{CONCLUSÃO}

O "fetiche da justificação racional das práticas de decisão do poder judiciário é, na verdade, um fetiche moral que envolve possibilidades de desenvolvimento claramente autoritárias" (MATOS; SOUZA, 2017, p. 304). A leitura de Souza, Matos e García Amado é 
confirmada diante da postura das mais variadas cortes constitucionais, inclusive o STF. Os dois casos analisados possuem uma importante semelhança, qual seja, a expansão do poder do Estado sobre a liberdade dos indivíduos, o que redunda na relativização de garantias básicas, suspendendo-se soberana e exceptivamente o Estado de Direito. Dessa maneira, a interpretação se equipara à lei e a fronteira entre lei e interpretação constitucional que, como dito por Barroso em seu voto na recente $\mathrm{ADO} \mathrm{n}^{\circ} 26$, normalmente é clara, fica menos nítida e acaba eclipsada. Assim como ocorre no estado de exceção permanente, cabe acrescentar. O que importa aqui não é o variável tema a ser decidido - que eventualmente pode ter sentido libertário ou progressista (assim como pode não ter) -, mas a permanente forma excepcional com que ele é tradado no cenário judicial.

É possível afirmar que as palavras de Barroso se aproximam de forma involuntária daquelas proferidas por Giorgio Agamben, para quem o estado de exceção é uma zona de indeterminação entre norma e fato. A intepretação e a produção normativa que o STF e todas as instâncias judiciárias realizam, atribuindo força de lei às suas decisões, só pode ocorrer diante dessa ausência de nitidez, dessa zona de indeterminação na qual os atos do Judiciário, independentemente de qualquer legitimidade democrática, assumem força de lei. O judiciário age assim à margem da legalidade e da Constituição, ocupando o centro vazio dessas dimensões nômicas. Na verdade, trata-se de condição fundamental para o exercício de poder nos Estados de Direito, pois só nesse espaço exceptivo e anômico é possível suspender e criar direito, excluir e incluir a norma ao talante dos inconfessáveis interesses de turno. O Poder Judiciário se põe como fora-da-lei, dado que não reconhece limites legais e constitucionais para sua atuação, a exemplo do soberano schmittiano. Com efeito, esses limites são constantemente suspensos e afastados pelos sopesamentos que aprofundam o ódio à democracia já característico do Estado Jurisdicional que opera a exceção interpretativa soberana.

A presente pesquisa nos levou a caminhos que revelaram que a função do Judiciário como último guardião da Constituição permite sua suspensão principalmente para ampliar o poder do Estado. Nesse sentido, último não assume apenas um sentido sequencial, mas também de força: o guardião decisivo e definitivo, que opera com a exceção. O uso de algumas decisões do Supremo Tribunal Federal não teve por finalidade esgotar o tema, mas evidenciar a sua existência e importância ao se ilustrar como a exceção opera por meio dos tribunais com base em teorias como as de Robert Alexy. Nesse sentido, a recorrência da prática da exceção interpretativa soberana não é tão relevante quanto a sua centralidade, que foi o que buscamos 
denunciar. Resta acrescentar que a ampliação do poder punitivista e violento do Estado parece ser bem aceita por certa parcela da sociedade, em especial as classes médias, desde que a atuação jurisdicional "criativa" se justifique mediante uma "racionalidade" jurídica e, em última instância, moral; aliás, é isso que guia as decisões dos juízes: o atendimento a valores pessoais, conectados a fatores raciais, sexuais, de gênero e de classe.

Tal como já demonstrou Agamben e muitos outros autores, a exceção funciona como um dispositivo de manutenção do Estado de Direito e dos direitos a ele fundamentais, isto é, a liberdade-privilégio e a propriedade, garantindo os interesses de classes privilegiadas que têm na exploração do trabalho alheio a garantia de sua perenidade. A exceção se revela na radicalização da violência própria do Estado, tendo na teoria interpretativista, com suas técnicas de ponderação e de proporcionalidade, mais uma ferramenta para o ocultamento dessa violência.

\section{REFERÊNCIAS}

AGAMBEN, Giorgio. Estado de exceção. Trad. Iraci D. Poleti. 2ed. São Paulo: Boitempo, 2007.

AGAMBEN, Giorgio. Homo sacer: o poder soberano e a vida nua. Trad. Henrique Burigo. $2^{\mathrm{a}}$ ed. Belo Horizonte: Editora UFMG, 2010.

ALEXY, Robert. Constitutional rights and proportionality. Revus Online: journal for constitutional theory and philosophy of law, n. 22, 2014a.

ALEXY, Robert. Teoria discursiva do direito. Trad. Alexandre Travessoni Gomes Trivisonno. Rio de Janeiro: Forense Universitária, 2014b.

ALEXY, Robert. Theorie der juristischen Argumentation. Frankfurt am Main: Suhrkamp, 1983.

ATIENZA, Manuel. A vueltas con la ponderación, 2014. Disponível em: $<$ https://edwinfigueroag.wordpress.com/2014/09/24/a-vueltas-con-la-ponderacion-manuelatienza-rodriguez-pdf/>. Acesso em: 1 mai. 2019.

BARROSO, Luís Roberto. Judicialização, ativismo judicial e legitimidade democrática. (Syn)thesis, v. 5, n. 1, 2012.

BARROSO, Luís Roberto. Neoconstitucionalismo e constitucionalização do direito (o triunfo tardio do direito constitucional no Brasil). Revista de Direito Administrativo, v. 240, 2005 . 
BENJAMIN, Walter. Origem do drama barroco alemão. Trad. Sergio Paulo Rouanet. São Paulo: Brasiliense, 1984.

BENJAMIN, Walter. Crítica da violência: crítica do poder. In: BENJAMIN, Walter. Documentos de cultura, documentos de barbárie: escritos escolhidos. Seleção e apresentação Willi Bolle. Trad. Celeste H. M. Ribeiro de Souza et all. São Paulo: Cultrix, pp. 160-175, 1986.

BENJAMIN, Walter. Sobre o conceito de história. In: BENJAMIN, Walter. Magia e técnica, arte e política: ensaio sobre literatura e história da cultura. Trad. Sérgio Paulo Rouanet. 7.ed. São Paulo: Brasiliense, pp. 222-232, 1994.

BRASIL. Constituição (1988). Constituição da república federativa do Brasil, Senado Federal, 1988.

BRASIL. Conselho Nacional De Justiça. Censo do poder judiciário. Brasília, 2014.

BRASIL. Supremo Tribunal Federal. Habeas Corpus 141.949. Relator: Ministro Gilmar Mendes. Paciente: Admys Francisco de Sousa Gomes. Autoridade Coatora: Superior Tribunal Militar. Brasília, DF, 16 de maio de 2016. Disponível em:

$<$ http://portal.stf.jus.br/processos/downloadPeca.asp?id=314183493\&ext=.pdf $>$. Acesso em: 25 de junho de 2020.

BRASIL. Supremo Tribunal Federal. Ação Direta de Inconstitucionalidade 855-2 Paraná. Relator: Ministro Gilmar Mendes. Requerente: Confederação Nacional do Comércio. Intimados: Governador do Estado do Paraná; Assembleia Legislativa do Paraná. Brasília, DF, 06 de março de 2008. Disponível em:

$<$ http://redir.stf.jus.br/paginadorpub/paginador.jsp?docTP=AC\&docID=583759>. Acesso em: 21 de abril de 2019.

BRASIL. Supremo Tribunal Federal. Habeas Corpus 126292. Relator: Ministro Teori Zavascki. Paciente: Marcio Rodrigues Dantas. Autoridade Coatora: Relator do HC No 313.021 do Superior Tribunal de Justiça. Brasília, DF, 16 de maio de 2016. Disponível em: <http://redir.stf.jus.br/paginadorpub/paginador.jsp?docTP=TP\&docID=10964246>. Acesso em: 21 de abril de 2019.

BRASIL. Presidência da República. Casa Civil. Subchefia para Assuntos Jurídicos. Decretolei no 3.689, de 3 de outubro de 1941. Código de Processo Penal. Rio de Janeiro, 3 out. 1941. Disponível em: <http://www.planalto.gov.br/ccivil_03/decreto-lei/Del3689.htm>. Acesso em: 15 abril 2019

BRASIL. Presidência da República. Casa Civil. Subchefia para Assuntos Jurídicos. Decretolei $\mathrm{n}^{\circ}$ 2.848, de 7 de dezembro de 1940. Código Penal. Rio de Janeiro, 7 dez. 1940. Disponível em: <http://www.planalto.gov.br/ccivil_03/decreto-lei/Del2848compilado.htm>. Acesso em: 12 abril 2019 
BRASIL. Presidência da República. Casa Civil. Subchefia para Assuntos Jurídicos. Decretolei no 2.848, de 7 de dezembro de 1940. Código Penal Militar. Brasília, 21 out. 1969. Disponível em: <http://www.planalto.gov.br/ccivil_03/decreto-lei/Del2848compilado.htm>. Acesso em: 12 abril 2019

BRASIL. Presidência da República. Casa Civil. Subchefia para Assuntos Jurídicos. Decreto $n^{0}$ 678, de 6 de novembro de 1992. Promulga a Convenção Americana sobre Direitos Humanos (Pacto de São José da Costa Rica), de 22 de novembro de 1969. Brasília, 6 nov. 1992. Disponível em: <http://www.planalto.gov.br/ccivil_03/decreto/d0678.htm>. Acesso em: 12 abril 2019.

BURKE, Edmund. Reflections on the revolution in France. Org. Frank M. Turner. New Haven: Yale University Press, 2003.

CARBONELL, Miguel; GARCÍA JARAMILLO Leonardo. El canon neoconstitucional. Bogotá: Universidad Externado de Colombia, 2010.

CARBONELL, Miguel. EI neoconstitucionalismo: significa y biveles de análisis. In: CARBONELL, Miguel; GARCÍA JARAMILLO Leonardo. El canon neoconstitucional. Bogotá: Universidad Externado de Colombia, pp. 159-172, 2010.

CHEMERINSKY, Erwin. Constitutional law: Principles and Policies. New York: Wolters Kluwer, 2015.

COSTA, Pietro. Os "senhores da lei". Lei, interpretação e liberdade no iluminismo jurídico. Trad. Ricardo Sontag. Revista da Faculdade de Direito da UFMG, Belo Horizonte, n. 69, 2016.

COSTA, Pietro. Soberania, representação e democracia: ensaios de história do pensamento jurídico. Trad. Ricardo Marcelo Fonseca, et al. Curitiba: Juruá, 2010.

COVER, Robert M. Violence and the word. The Yale Law Journal, n. 95, pp. 1601-1629, 1985-1986.

DEENER, David. Judicial review in modern constitutional systems. The American Political Science Review, v. 46, n. 4, pp. 1079-1099, 1952.

DIMOULIS, Dimitri. Anotações sobre o "neoconstitucionalismo" (e sua crítica). Faculdade de Direito GV, São Paulo, n. 17, mar. 2008.

DWORKIN, Ronald. Law's Empire. Cambridge: The Belknap Press of Harvard University Press, 1986.

FERRAJOLI, Luigi. Los fundamentos de los derechos fundamentales. Madri: Trotta, 2014.

GARCÍA AMADO, Juan Antonio. Sobre ponderaciones. Debatiendo com Manuel Atienza. Sucre: Universidad Mayor Real y Pontificia de San Francisco Xavier de Chuquisaca, 2014. 
MATOS, Andityas Soares de Moura Costa; MILÃO, Diego Antonio Pierini. Decisionismo e hermenêutica negativa: Carl Schmitt, Hans Kelsen e a afirmação do poder no ato interpretativo do direito. Sequência, Florianópolis, n. 67, pp. 111-137, 2013.

MATOS, Andityas Soares de Moura Costa; SOUZA, Joyce Karine de Sá. Sobrevivências do nazifascismo na teoria jurídica contemporânea e seus reflexos na interpretação judicial brasileira. Revista de Estudos Constitucionais, Hermenêutica e Teoria do Direito, Porto Alegre, pp. 295-310, set.-dez. 2017.

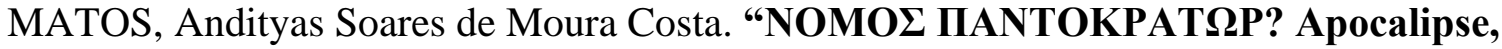
exceção, violência. Revista Brasileira de Estudos Políticos, Belo Horizonte, n. 105, pp. 277342, jul.-dez. 2012.

MATOS, Andityas Soares de Moura Costa. Representação política contra a democracia radical: uma arqueologia (a)teológica do poder separado. Belo Horizonte: Fino Traço, 2019.

MENDES, Gilmar Ferreira. Curso de direito donstitucional. 12. ed. São Paulo: Saraiva, 2017.

POZZOLO, Susanna. Neoconstitucionalismo y la especificidad de la interpretacion constitucional. Alicante: Biblioteca Virtual Miguel de Cervantes, 1998.

ROSSITER, Clinton. Constitutional dictatorship crisis government in the modern democracies. Nova York: Routledge, 2013.

RUFFIA, Paolo Biscaretti di. Les constitutions européenes: notions introductives. In RUFFÍA, Paolo Biscaretti di; ROZMARYN, Stefan. La constitution comme loi fondamentale. Torino: Giappichelli, p. 3-22, 1966.

SCHMITT, Carl. O conceito do político. Trad. Alvaro L. M. Valls. Petrópolis: Vozes, 1992.

SCHMITT, Carl. O nomos da terra no direito das gentes do jus publicum europaeum. Trad. Alexandre Franco de Sá, Bernardo Ferreira, José Maria Arruda e Pedro Hermílio Villas Bôas Castelo Branco. Rio de Janeiro: Contraponto, 2014.

SCHMITT, Carl. Political theology: four chapters on the concept of sovereignty. Trad. George Schwab. Chicago: University of Chicago Press, 2005.

SILVA, Virgílio Afonso da. O proporcional e o razoável. Revista dos Tribunais, n. 798, pp. 23-50, 2002. Disponível em:

<http://www.revistas.unifacs.br/index.php/redu/article/viewFile/1495/1179>. Acesso em: 9 jun. 2017.

WOOD, Ellen Meiksins. Democracy against capitalism: renewing historical materialism. Cambridge: Cambridge University Press, 2003. 
ZOLO, Danilo. Teoria e crítica do Estado de Direito. In: COSTA, Pietro; ZOLO, Danilo (orgs.). O Estado de Direito: história, teoria, crítica. Tradução de Carlos Alberto Dastoli. São Paulo: Martins Fontes, 2006.

Trabalho recebido em 16 de maio de 2019

Aceito em 05 de dezembro de 2020 